Ks. Stanisław LONGOSZ

(Lublin, KUL)

\title{
MEDYCZNA TROSKA O LUDZI STARYCH W STAROŻYTNYM GRECKO-RZYMSKIM ŚWIECIE
}

Przy omawianiu różnorodnej tematyki starości i zapobiegania lub leczenia jej dolegliwości, warto dla całości problemu także przypomnieć, choćby ogólnie, co na ten temat wiedzieli, mówili i stosowali ówcześni medycy; jak oni traktowali ten okres życia ludzkiego oraz jakie podsuwali rady i środki, by leczyć lub ulżyć jego słabościom. W wystapieniu tym zatem scharakteryzujemy najpierw tę problematykę w okresie przedchrześcijańskim, w oparciu głównie o pisma tzw. Corpus Hippocraticum, w drugiej zaś części wykorzystamy w oparciu o twórczość medyków okresu patrystycznego (głównie Galena); ich bowiem poglądy wpływały niewątpliwie również wielokrotnie na wypowiedzi Ojców Kościoła.

\section{KURACJA LUDZI STARYCH W OKRESIE PRZEDCHRZEŚCIJAŃSKIM}

Już na wstępie trzeba zaznaczyć, że medycyna starożytna, nie znająca prawie żadnej specjalizacji, nie wypracowała i nie pozostawiła po sobie specjal-

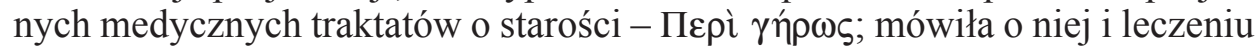
jej dolegliwości tylko przy omawianiu lub leczeniu innych chorób ${ }^{1}$. Starości bowiem nie traktowano jako jakiejś nieuleczalnej choroby, ale jako nieuchronny naturalny okres każdej istoty żywej ( $\zeta \hat{\omega} o v)$, która pod koniec swego życia z natury odczuwa pewne dolegliwości. Nie znamy więc specjalnych traktatów o starości, bo ich najprawdopodobniej nie było, choć nie można wykluczyć, że mówiono o niej praktycznie lub teoretycznie przy omawianiu innych chorób czy m.in. długości życia, jak np. w zaginionym, ale wspominanym jeszcze

${ }^{1}$ Por. Ch. Gnilka, Greisenalter, RACh XII, Stuttgart 1985, 995-1094, spec. 1030-1032 (Medizin); G. Magdelaine, Vieillesse et médecine chez les médecins grecs d'Hippocrate à Galien, w: L'ancienneté chez les anciens, ed. B. Bakhouche, Montpellier 2003, 61-82; G. Pisi, La medicina greca antica, w: Senectus. La vecchiaia nell'antichità, ed. U. Mattioli, vol. 1: Grecia, Bologna 1995, 447-486; I. Mazzini, La geriatria di epoca Romana, w: tamże, t. 2: Roma, Bologna 1995, 339363; inne zob. niżej S. Longosz, Starość w starożytności klasycznej i chrześcijańskiej. Materiały bibliograficzne, VoxP 31 (2011) t. 56, . 


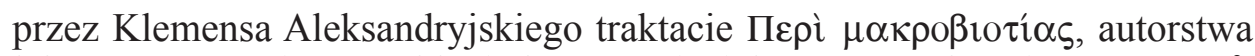
lekarza M. Artoriusza Asklepiadesa, przyjaciela cesarza Oktawiana Augusta². Tak więc gerontologia, zajmująca się badaniem przyczyn i sposobów leczenia, jak i geriatria interesująca się leczeniem chorób i dolegliwości wieku starczego, są pojęciami i dyscyplinami nowymi, powstałymi dopiero na początku $\mathrm{XX}$ wieku3 ${ }^{3}$. Starości, jak wspominaliśmy, nie traktowano jako choroby, ale jako naturalny okres życia człowieka, również jako problem antropologiczny, stąd też zajmowali się nią od początku także filozofowie, pisząc zachowane

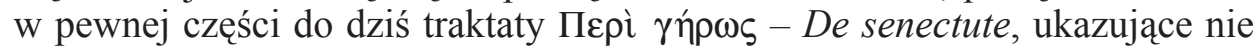
tylko jej słabości i dolegliwości, ale często konsolacyjnie jej walory - mądrość, roztropność i doświadczenie, które równoważyły jej braki i słabości; w ten sposób filozof był również lekarzem i terapeutą starości ${ }^{4}$.

To właśnie u presokratyków powstała słynna teoria o cieple i wilgoci, przyjmowana później powszechnie w mniej lub więcej zmodyfikowanej formie przez filozofów przyrody i medyków starożytnych, głosząca, że każda

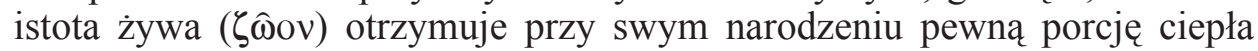
i wilgoci, które z biegiem życia powoli się wyczerpują, tak iż pod koniec staje

${ }^{2}$ Por. Gnilka, Greisenalter, RACh XII 1030-1031; M. Wellmann, Artorius 4, RE II/2 1461; Clemens Alexandrinus, Paedagogus II 23, 1, SCh 108, 54: „Pewien Artoriusz w swoim traktacie

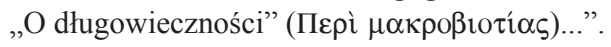

3 Por. J. Freeman, The history of geriatrics, „Annales Med. Hist.” 10 (1938) 324-335; J. Steudel, Zur Geschichte der Lehre von den Greisenkrankheiten, „Sud. Arch. Gesch. Med. Nat. Wiss.” 35 (1942) 1-27; A. Ruiz Moreno, Notas para la historia de las enfermedades de la vejez, „Humana Studia” 6 (1954) 105-111; S. Rosa Burstein, The historical background of gerontology, „Geriatrics” 10 (1955) 189-193; taż, The foundation of geriatrics, „Geriatrics” 12 (1957) 494-499; M.D. Grmek, On ageing and old age. Problems and historic aspects of gerontology and geriatrics,

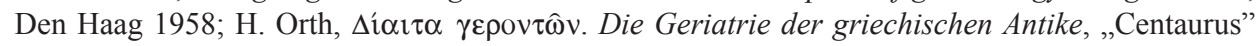
8 (1963) 19-47; P. Lüth, Geschichte der Geriatrie, Stuttgart 1965; F. Boulière, Storia della medicina, della farmacia e della veterinaria, VI, Bergamo 1982, 83-109; S. Byl, La gérontologie de Galien, „History and Philosophy of the Life Sciences” 10 (1988) 73-92.

${ }^{4}$ Do najbardziej znanych tego rodzaju traktatów, będących równocześnie swego rodzaju filozoficznymi konsolacjami, należy Cato Maior de senectute Cycerona, który niejako ustalił ich strukturę ukazującą najpierw cienie starości (vituperatio senectutis), a potem jej blaski (laudatio senectutis). Autorami zaś, którzy takie traktaty pisali, lub znaczną ich część poświęcili starości, należą: Pitagoras z Samos (VI w.), Demokryt z Abdery (460-370), Platon (427-347) - Politeia I 328c-360d, Arystoteles (384-322), Teofrast z Erezu (372-287), Demetriusz z Faleronu (350-283), Aryston z Chios, Warron

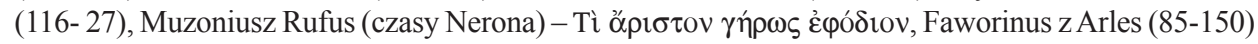

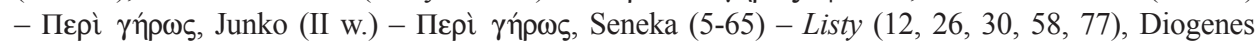
z Onidy (II w.) i Plutarch z Cheronei (50-125). Również żyjący w V wieku Jan Stobajos gromadząc w swojej antologii wypowiedzi na temat starości (Joannis Stobaei Florilegium, ed. Meineke, IV,

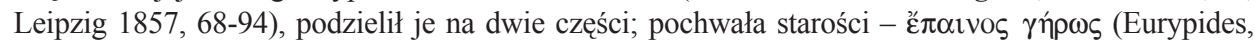
Menander, Aleksidos z Demetrion, Sofokles, Ajschylos, Antifanes, Faworinus z Arles, Plutarch,

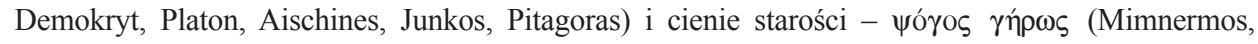
Eurypides, Menander, Theognidos, Ferekrates, Antifanes, Filemon, Aleksidos, Sofron, Mimnermos, Apollodor, Demokryt, Faworinus z Arles, Junkos, Platon i Muzoniusz Rufus). 
się ona zimna i wysuszona, a ich wyczerpanie oznacza dla niej śmierć; ich obecność jest warunkiem zapewniającym narodziny i wzrost istot żywych, a brak choćby jednego $\mathrm{z}$ tych elementów, prowadzi do upadku biologicznego ${ }^{5}$. Echa tej właśnie teorii spotykamy w zachowanych fragmentarycznie pismach presokratyków greckich ${ }^{6}$.

Tak więc dla Talesa (VII/VI w.) „pokarmem wszystkich rzeczy jest wilgoć” (11,A 12), a „ciepło żyje dzięki wilgoci” (A 13)7. Dla Anaksymandra (610-540) „wszystkie byty żyjące wywodzą się z wilgoci, która ulatnia się ze słońca" $(12, \mathrm{~A} 11,6)^{8}$. Hippon z Samos (V w.), który traktował wodę jako principium i jako duszę" (38,A 10), twierdził, że „starzy się wysuszają” (A 11) Dla Parmenidesa z Elei (Vl/V w.) ,starość powstaje ze zmniejszania się ciepła" (28,A 46a). Dla Empedoklesa z Akragas (490-430) ciepło ma związek ze wzrastaniem (31,A 77), a oziębianie ze snem i śmiercią (A 85). Podobnie ciepło miało szczególny związek z rodzeniem nowego życia dla Filolaosa z Krotony (44,A 27), dla pitagorejczyków ${ }^{10}$, dla Diogenesa z Apolonii (64,A 28 i A 24) i Demokryta (68,A 117 i B 5) ${ }^{11}$, a wcześniej dla Heraklita (VI/V w.) ,dla dusz to przyjemność lub śmierć stać się wilgotnymi” (B 77a), a „dusza sucha jest najmądrzejsza i najlepsza" (B 118) ${ }^{12}$.

Teorię o cieple, i wilgoci przejął również niemal w całości i uczynił podstawą swego systemu leczenia twórca medycyny Hipokrates z Kos (460-367) i podzielający jego metodologię późniejsi uczniowie-hipokratycy (od 2. poł. V do końca IV w. prz. Chr.), których pisma (w liczbie ok. 56) pod imieniem mistrza tworzą tzw. Corpus Hippocraticum ${ }^{13}$. Nie ma wśród nich niestety, żad-

${ }^{5}$ Por. G.E.R. Lloyd, The hot and the cold, the dry and the wet in Greek philosophy, ,Journal of Hellenic Studies" 84 (1964) 92-106; Pisi, La medicina greca antica, s. 447-481.

${ }^{6}$ Por. Pisi, La medicina greca antica, s. 451.

${ }^{7}$ Por. H. Diels, Die Fragmente der Sokratiker, Berlin 1912, 9, 2; Aristoteles, Metaphysica I 3, 983 b 17, thum. W. Heinrich: Zarys historii filozofii, I/1, Poznań 1925, 18: „Tales mówi, że początkiem wszystkiego jest woda... widział on, że pokarm wszystkich istot jest wilgotny i że samo ciepło powstaje z wilgoci i nią żyje, a to, z czego wszystko powstaje, jest jego początkiem..., a także fakt, że zarodki wszystkich istot mają wilgotną naturę, woda zaś jest u wszystkich rzeczy wilgotnych początkiem tej natury”.

${ }^{8}$ Por. Hippolytus, Refutatio I 6, 1-7, Diels 13, 4-3, thum. Heinrich, s. 20: „Anaksymander Milezyjczyk uważał... że istoty żyjące powstają z wilgoci wyparowanej przez słońce”.

${ }^{9}$ Por. Simplicius, In Aristotelis physicorum libros commentaria 23, 71, Diels 9, 14, thum. Heinrich, s. 18-19: „Tales syn Eksamyasta i Hippon mówią, że początkiem wszystkiego jest woda, naprowadzeni na to obserwacją zjawisk, albowiem to, co ciepłe, żyje wilgocia, a co umarłe, wysycha, zarodki zaś wszystkiego są mokre, a wszelki pokarm soczysty”.

${ }^{10}$ Por. Diogenes Laertius, Vita philosophorum VIII 28, thum. W. Olszewski: Diogenes Laertios, Żywoty i poglady stynnych filozofów, Warszawa 2004, 483.

${ }^{11}$ Por. Pisi, La medicina greca antica, s. 451.

${ }^{12}$ Por. thum. Heinrich, s. 37; zob. K. Mrówka, Heraklit. Fragmenty, nowy przekład i komentarz, Warszawa 2004, 216 i 320.

${ }^{13}$ Por. ed. E. Littré, Oeuvres complètes d'Hippocrate, vol. I-IX, Paris 1839 (ristamp. Amsterdam 
nej medycznej monografii o starości, choć nie brakuje w nich wielu uwag na jej temat, które niewątpliwie tworzą zalążki przyszłej geriatrii. Starość opisywana jest w nich często już nie tylko w terminologii antropologicznej, ale również biologicznej i terapeutycznej ${ }^{14}$. Rozpoczynała się ona w nich ogólnie ok. 60. roku życia, choć zwolennicy szeroko rozpowszechnionej teorii hebdomadycznej, poświadczonej już przez Solona, a utrwalonej w przypisywanym

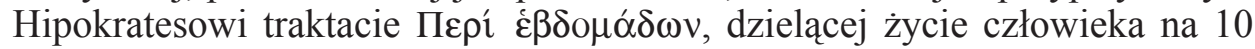
okresów po 7 lat, precyzowali, że zajmuje ona dwa ostatnie: wiek $\pi \rho \varepsilon \sigma \beta \hat{\tau} \tau \eta \varsigma$ (lata 49-56) i wiek $\gamma \varepsilon ́ p \omega v$ (lata od $56 \mathrm{roku})^{15}$. Główną tezą hipokratyków była teoria antropologiczna o cieple wrodzonym (દ̌́ faktorze życia każdej istoty żywej ( $\zeta \hat{\omega} o v)$, napędowym elemencie w procesie morfogenetycznym z siedzibą w sercu. Ciepło i zimno, wilgotność i suchość, mieszając się z sobą określały też zdrowie i chorobę każdej istoty żywej, będąc również odpowiedzialne za jej urodzenie, wzrost i proces starzenia się. To ostatnie było w konsekwencji naturalnym procesem oziębiania się i wysuszania organizmu. Według Hipokratesa każda istota żywa w dniu swych narodzin otrzymuje największą porcję ciepła i wilgoci, a w ostatnim ma ich już najmniej, ponieważ na początku mają miejsce największe metaboliczne procesy wzrastania, które przy końcu wygasają ${ }^{16}$. W związku z tym ludzie starzy, $\mathrm{w}$ przeciwieństwie do jeszcze rosnących, mają już mało wrodzonego ciepła i wilgoci, w konsekwencji czego potrzebują już mniej pokarmu, a w wypadku choroby mają też już mniej gwałtowną gorączkę ${ }^{17}$; łatwiej też znoszą głód, w przeciwieństwie do młodych ${ }^{18}$, bo przy jedzeniu należy też uwzględniać wiek $^{19}$. Przy tej okazji hipokratycy przypominają, co organizmowi żywemu,

1973); tu posługuję się nowszym wydaniem: ed. W.H.S. Jones: Hippocrates, Works, vol. I-IV, Cambridge Mass. - London 1957-1959, Loeb. Pod imieniem Hipokratesa ujęte są tu też pisma hipokratyków.

${ }^{14}$ Por. S. Byl, La vieillesse dans le Corpus Hippocratique, w: Formes de pensée dans la Collection Hippocratique. Actes du IV Colloque Internationale Hippocratique (Lausanne, 21-26 IX 1981), ed. F. Lasserre - P. Mudry, Genève 1983, 85-95; A. Debru, Médecin et malade dans la Collection Hippocratique: interrogatoire ou dialogue?, w: Médecine antique, ed. P. Demont, Amiens 1991, 35-50; Pisi, La medicina greca antica, s. 452-469.

${ }^{15}$ Por. Clemens Alexandrinus, Stromata VI 144, 4-6; Pisi, La medicina greca antica, s. 456; Gnilka, Greisenalter, s. 997-998.

${ }^{16}$ Por. Hippocrates, De natura hominis 7 i 12.

${ }^{17}$ Por. Hippocrates, Aphorismi I 14, ed. Jones IV 104, tłum. H. Łuczkiewicz, Warszawa 1864, 16: „Kto rośnie, ten ma największy zapas ciepła wrodzonego, najwięcej zatem potrzebuje pokarmu... Starzec przeciwnie, posiada mało ciepła, z którego też powodu mało potrzebuje pokarmu, a zbytek umarza go. Dla tej też przyczyny gorączka u starca nie jest gwałtowna, albowiem chłodnym jest jego ciało".

${ }^{18}$ Por. tamże I 13, ed. Jones IV 104, Łuczkiewicz, s. 16: „Głód najłatwiej znoszą starcy, a po nich osoby średniego wieku; ; trudniej zniesie go młodzieniec, najtrudniej zaś dziecko”.

${ }_{19}$ Por. tamże I 15, ed. Jones IV 104-110, Łuczkiewicz, s. 17: „Kiedy bowiem posiadamy najwięcej ciepła wrodzonego, najwięcej tym samym potrzebujemy pokarmów. Okres wieku i atleci wskazują na to prawidłowo". 
zwłaszcza choremu, daje ciepło - ułatwia gojenie się ran i znoszenie bólu, zmiękcza skórę, uśmierza dreszcze, skurcze i ociężałość głowy, a w ogóle „,iepło sprzyja i sprawia przesilenie choroby, gdy przeciwnie - zimno razi i przynosi zgubę"20.

Wspominaliśmy wyżej, że od ilości i układu ciepła i wilgoci w organizmie zależało według hipokratyków jego zdrowie lub choroba. Obok tego przyjmowali, że źródłem powstawania chorób było też wadliwe połączenie się czterech istniejących w organizmie cieczy - krwi, śluzu oraz czarnej i żółtej żółci (sanguis, mucus, atra et flava bilis), wywoływane przez wpływy zewnętrzne (powietrze, bagna, klimat, pory roku) lub wewnętrzne (najczęściej dietetyczne) czy endemiczne (których siłami przyrody nie można wytłumaczyć). U nich też spotykamy najstarszy, przypisywany Hipokratesowi, katalog chorób i dolegliwości wieku starczego:

„Starcy ulegają dusznościom, katarom, nieżytom oskrzeli, trudnościom w oddawaniu moczu, cierpieniom stawów, chorobom nerek, zawrotom głowy, apopleksjom, cherlactwu, ogólnej świerzbiące ciała, bezsenności, śluzotokom oczu, nosa i jelit, osłabieniu wzroku, chorobom zaćmy i osłabieniu słuchu"21.

Zauważają też przy tym, że „,choroby nerek i pęcherza moczowego trudno się leczą u starców"22, a występująca u nich czkawka, po nieuzasadnionym przeczyszczeniu jest niezbyt dobrze rokującym objawem ${ }^{23}$, że kto w młodości nie miał kłopotów ze stolcem, będzie je miał w starości, i na odwrót ${ }^{24}$, wyróżniając zaś w przebiegu choroby trzy stadia - okres surowizny ( $\alpha \epsilon \varepsilon \varphi^{\prime} \dot{\alpha} \alpha-$ cruditas),

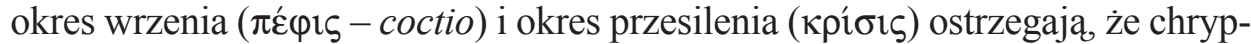
ka i nieżyt nosowy u ludzi starszych nie osiagają drugiego okresu ${ }^{25}$, gdy natomiast pojawi się nagły ból ucha z przeciagłą i silną gorączką, co w następstwie wywołuje często w uchu ropienie, to u osób młodszych powoduje on szybki

${ }^{20}$ Por. tamże V 22, ed. Jones IV 162, Łuczkiewicz, s. 54.

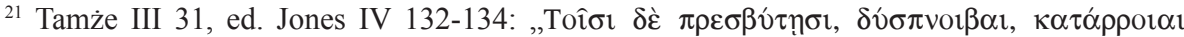

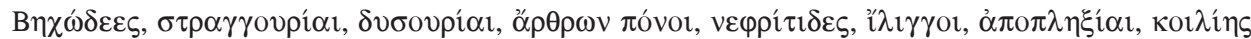

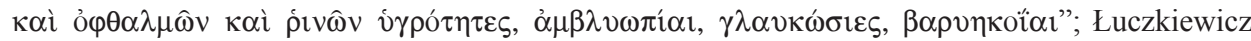
s. 35; zob. Pisi, La medicina greca antica, s. 465-466, nn. 79-80.

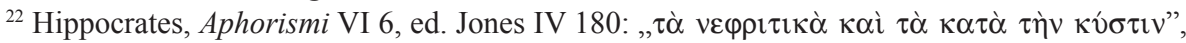
Łuczkiewicz, s. 66.

${ }^{23}$ Por. tamże VII 40, ed. Jones IV 202, Łuczkiewicz, s. 80: „Czkawka występująca u starców, którzy przebyli czyszczenie stolcowe, nie jest dobrym znakiem".

${ }^{24}$ Por. tamże II 20, ed. Jones IV 112, Łuczkiewicz, s. 21: „Kto w młodości miewa stolce wolne, ten w miarę starości będzie miał twarde; kto przeciwnie w młodości doświadcza zatwardzenia, ten w miarę starości ulegnie rozwolnieniom stolca"; tamże II 53, ed. Jones IV 120, Łuczkiewicz, s. 27: „Kto miewa stolce wolne, ma się w młodym wieku lepiej, niż ów, co ma zaparte; wszelako gorzej się ma na starość, albowiem z wiekiem stolce najczęściej stają się zaparte”.

${ }^{25}$ Por. tamże II 40, ed. Jones IV 118, Łuczkiewicz, s. 25: „Chrypka i nieżyt nosowy u zgrzybiałych starców nie osiaga okresu wrzenia"; zob. L. Bourgey, Observation et experience chez les médecins de la Collection Hippocratique, Paris 1953, 238. 
zgon, u starszych zaś opóźnia go, tym bardziej, że nierzadko jest on powrotem choroby $^{26}$. Informują przy tym, że osoby starsze chorują rzadziej, ale dłużej, nawet do końca życia ${ }^{27}$. Najzdrowszą dla nich porą roku jest lato i początek jesieni $^{28}$, na wiosnę bowiem, zwłaszcza suchą i przy północnych wiatrach, wnet ulegają śmiertelnym nieżytom ${ }^{29}$, w zimie zaś narażone są na ciągłe gorączki wywoływane przez zaziębienia i częste zaparcia ${ }^{30}$; na ich zdrowie wpływa też okolica: tak na przykład w północnej zimnej Scytii wiele osób po 50. roku życia ulega często częściowemu porażeniu ${ }^{31}$. Zwracali też uwagę na fizyczną sylwetkę osób starszych: wysoka i smukła budowa ciała na starość bywa niewygodna i szkodliwsza od niskiej32; starzy też, choć niekiedy są słabi, jako doświadczeni i nawykli do pracy, łatwiej i lepiej ją wykonują niż młodzi i silni ${ }^{33}$.

Oto kilkanaście rozrzuconych i niespójnych uwag Hipokratesa i jego bezpośrednich uczniów - hipokratyków na temat starości, jej objawów oraz rokowań i leczenia jej dolegliwości. Opierając się na wcześniejszej teorii wrodzonego ciepła i wilgoci uważali, że jej leczenie polega przede wszystkim na ich regulowaniu w organizmie człowieka" 34 .

Do upowszechnienia poglądów hipokratyków przyczynił się później w dużej mierze Arystoteles (384-322), który prezentując w swych pismach biologiczno-fizjologiczną stronę człowieka nie tylko w pełni podzielał i filozoficznie pod-

${ }^{26}$ Por. Hippocrates, Prognostica III 15-15, ed. Jones II 12, Łuczkiewicz, s. 122: „Nagły ból ucha z przeciągłą i silną gorączka, jest niebezpieczny: grozi on bowiem majaczeniem i śmiercią chorego... choroba ta u młodszych osób sprowadza zgon już siódmego dnia, a nawet wcześniej, u starszych zaś daleko później, gdyż u tych ani gorączka ani majaczenie nie objawiają się zaraz, dla której to przyczyny szybciej wywiązuje się w uchu ropienie. Osoby podeszłego wieku umierają też po większej części wskutek występujących powrotów choroby, gdy tymczasem młodsi giną wcześniej, zanim wystąpi ropienie w uchu".

${ }^{27}$ Por. Hippocrates, Aphorismi II 39, ed. Jones IV 118, Łuczkiewicz, s. 25: „Starzy chorują na ogół mniej niż młodzi; gdy jednak ulegną chorobie, nie pozbywają się jej zazwyczaj aż do końca życia"; tenże, De morbis I 22, ed. Jones I 178-180.

${ }^{28}$ Por. Hippocrates, Aphorismi III 18, ed. Jones IV 128, Łuczkiewicz, s. 32: „co do pór roku... młodzieży najlepiej służy wiosna i początek lata, starcom - lato i początek jesieni”.

${ }^{29}$ Por. tamże III 12, ed. Jones IV 124, Łuczkiewicz s. 31: „Kiedy po łagodnej zimie nastapi sucha przy północnych wiatrach wiosna... starcy w krótkim czasie ulegają zabójczym nieżytom”.

${ }^{30}$ Por. Hippocrates, De aere, aquis et locis 7, ed. Jones I 84, thum. H. Łuczkiewicz: Dwie ksiegi Hipokratesa: O powietrzu, wodach i okolicach i O lecznictwie pierwotnym, Warszawa 1890, 23: „W zimie... starsi zapadają na gorączki pałające z powodu zapartych stolców”.

${ }^{31}$ Por. tamże 3, ed. Jones I 76, Łuczkiewicz, s. 14: „Po pięćdziesiątym roku życia ulegają tamtejsi mieszkańcy częściowemu porażeniu w następstwie spływającej z głowy cieczy, gdy głowa nagle od słońca rozgrzana lub silnie oziębiona zostanie".

${ }^{32}$ Por. Hippocrates, Aphorismi II 54, ed. Jones IV 120, Łuczkiewicz, s. 27: „Wysmukła budowa ciała czyni człowieka w młodości swobodnym i nieszpetnym; na starość zaś staje się niewygodną i szkodliwszą od niskiej".

${ }^{33}$ Por. tamże II 49, ed. Jones IV 120, Łuczkiewicz, s. 26: „Kto nawykł do pewnej pracy, uskuteczni ją łatwiej, chociaż jest stary i słaby, aniżeli młody i silny, gdy do niej nie był przyzwyczajony".

${ }^{34}$ Por. Hippocrates, De prisca medicina 13-16, 18, 22, 24, ed. Jones I 34-63, Łuczkiewicz, s. 100-129. 
budował teorię o wrodzonym cieple i wilgoci, uważając, że starość zasadza się przede wszystkim na wyziębieniu i wysuszeniu żywego organizmu, ale nawet napisał związane z tym tematem dwa małe traktaty: O młodości i starości (Пepi

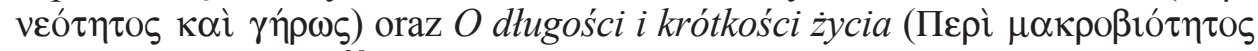

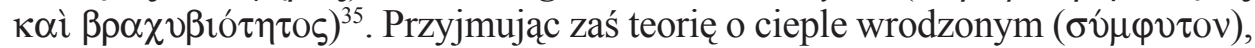
które nazywał też „,ciepłem naturalnym” ( $\varphi v \sigma ı$ kòv) z siedzibą w sercu, otrzymywanym wraz z naturą ${ }^{36}$, które nie tylko ogrzewa organizm, ale również zapewnia mu wzrost $i$ trawienie oraz jest nieodzownym gwarantem życia, a jego całkowite wyczerpanie lub zniszczenie oznacza zawsze śmierć, przyczyną zaś zmniejszania się ciepła wrodzonego jest ciągłe wyczerpywanie się elementu wilgotnego, którym się żywi ciepło ${ }^{37}$. Od ilości i jakości tego ciepła i wilgoci w organizmie zależy również długość życia: dlatego też należy się starać, by ta wilgoć w nim nie wysychała, była w nim nie tylko obfita, ale także ciepła. Stagiryta zaznaczał ponadto, że osobniki płci męskiej szybciej się starzeją, jeśli oddają się ciężkiej pracy, która wysusza, lub jeśli są zbyt lubieżne, bo się wysuszają przez wydalanie nasienia; one też żyją dłużej, niż płeć żeńska, bo są od niej istotami gorętszymi ${ }^{38}$. Podobnie embrion żeński, dopóki jest w łonie matki,

${ }^{35}$ Por. Aristoteles, De iuventute et senectute 467b-470b, thum. P. Siwek: Arystoteles, Krótkie rozprawy psychologiczno-biologiczne, BKF 95, Warszawa 1971, 114-123; De longitudine et brevitate vitae 464b-467b, tamże, s. 102-111; wiele na ten temat pisał również w traktacie De generatione animalium 715a-789b, tłum. P. Siwek: Arystoteles, O rodzeniu się zwierzat, BKF 130, Warszawa 1979.

${ }^{36}$ Por. Aristoteles, De generatione animalium 737a 6-7; De partibus animalium 650a 14.

${ }^{37}$ Por. Aristoteles, De iuventute et senectute 4-6, 469b, Siwek, s. 120-121: „Wszystkie części zwierząt $[=$ istot żywych $=\zeta \hat{\omega} \alpha]$ i całe ich ciało posiadają z natury ciepło wrodzone. Dlatego, dopóki żyją, są z całą oczywistością ciepłe; lecz jako zmarłe i pozbawione życia, mają własności wręcz przeciwne. Przeto w zwierzętach posiadających krew zasada tego ciepła musi się koniecznie znajdować w sercu, a u zwierząt pozbawionych krwi w organie analogicznym. Chociaż bowiem wszystkie [części ciała] za pomocą ciepła wrodzonego przyrządzają i trawią pokarm, najważniejszą rolę odgrywa w tym względzie [organ] główny - serce. Dlatego chociażby inne części oziębły, życie trwa nadal; lecz gdy ta część [wyziębnie], zwierzę bezwzględnie ginie; ponieważ do tego miejsca jest przywiązana zasada ciepła dla wszystkich [innych części] i zasada duszy, która poniekąd płonie w tych częściach, tj. w sercu zwierząt krwistych i w organie analogicznym zwierząt bezkrwistych. Stąd też życie i zachowanie tego ciepła z konieczności istnieją równocześnie; a to, co zwiemy śmiercią, jest zniszczeniem tego ciepła... Wyczerpaniem zowiemy zniszczenie [ognia], pochodzące od niego samego; wygaśnięciem zaś zniszczenie [ognia] mające swe źródło w przeciwieństwach. Pierwsze pochodzi od starości, drugie zaś od przemocy. Lecz w rzeczywistości jedno i drugie jest skutkiem tej samej przyczyny. Gdy mianowicie braknie pożywienia i ciepło nie jest więcej w stanie go wchłaniać, ogień ginie. $Z$ chwilą bowiem, gdy [element] przeciwny zatrzymuje trawienie, nie pozwala ogniu się żywić... Każde jestestwo żywe posiada duszę. Lecz ona, jak mówiliśmy, nie istnieje bez ciepła wrodzonego".

${ }^{38}$ Por. Aristoteles, De longitudine et brevitate vitae 5, 466a-b, tłum. P. Siwek, s. 107-108: „Musimy dobrze zrozumieć, że zwierzę jest z natury swej wilgotne i ciepłe, i że życie nosi te same cechy; przeciwnie, starość jest sucha i zimna podobnie jak trup; jasno to widać [z doświadczenia]. Lecz na materię ciał w takich jestestwach składają się elementy ciepły i zimny, suchy i wilgotny. Z konieczności zatem jestestwa, które się starzeją, wysychają. Dlatego należy [się starać], by element wilgotny nie wysychał szybko [...] . Z drugiej strony element wilgotny nie powinien być w małej 
rozwija się wolniej niż męski, gdy jednak znajdzie się poza nim, szybciej dojrzewa i starzeje się, bo jest słabszy ${ }^{39}$. A w ogóle ,,istoty żywe zbyt tłuste szybko się starzeją; mają bowiem niewielki zapas krwi, bo ta zużywa się na tworzenie tłuszczu, przez co zmierzają do swojej zguby"

Oprócz powyższych uwag na temat starości, związanych głównie z teorią o wrodzonym cieple i wilgoci, Arystoteles wymienia też szereg jej dolegliwości, jak: osłabienie zdolności seksualnych, a nawet fizjologiczna aspermia ${ }^{41}$, osłabienie wzroku spowodowane stwardnieniem i pomarszczeniem się rogów$\mathrm{ki}^{42}$, ciemniejsze zabarwienie skóry spowodowane wysychaniem krwi u osób

ilości [w zwierzętach]; bo co jest w małej ilości, łatwo wysycha [...]. Jestestwa większe posiadają więcej elementu wilgotnego. Jednak nie dla tej jedynie przyczyny żyją one dłużej. Dwie przyczyny na to się składają: ilość i jakość; konsekwentnie element wilgotny musi być nie tylko obfity, lecz także ciepły, by nie marzł łatwo i wysychał. Dla tej to właśnie przyczyny człowiek dłużej żyje niż niektóre [zwierzęta] większe [od niego]. Zwierzęta bowiem, których element wilgotny jest mniej obfity, dłużej jednak żyją, jeżeli jego jakość przewyższa proporcjonalnie brak ze strony jego ilości [...]. Toteż [zwierzęta] lubieżne i te, które obfitują w nasiona, szybko się starzeją. W rzeczy samej nasienie jest produktem wydzielniczym, a gdy odchodzi [od organizmu] wysusza go [...]. To samo należy powiedzieć o tych osobnikach płci męskiej, którzy oddają się ciężkiej pracy - dzięki niej prędzej się starzeja; praca bowiem wysusza, a starość jest właśnie suchą. Jednak można powiedzieć, że z natury i z ogólnej reguły płeć męska żyje dłużej niż płeć żeńska, a to dlatego, że osobnik płci męskiej jest zwierzęciem gorętszym od osobnika płci żeńskiej”.

${ }^{39}$ Por. Aristoteles, De generatione animalium IV 6, 775a, Siwek, s. 199-200: „Embriony żeńskie nie rozwijają się w matkach w taki sam sposób jak embriony męskie. Bo w łonie matki embrionowi żeńskiemu potrzeba dłuższego czasu niż embrionowi męskiemu do tego, by się rozwinął. Lecz gdy wyjdzie już na światło dzienne, wszystko następuje w nim szybciej: dojrzewanie płciowe, wiek dojrzały i starość, bo kobiety są z natury słabsze i zimniejsze. Toteż należy uważać kobiecość za rodzaj naturalnej deformacji. Dopóki embrion żeński jest wewnątrz matki, różnicowanie jego części dokonuje się wolno z powodu jego zimna (bo rozwój jest rodzajem gotowania, którego dokonuje ciepło; jeśli rzecz jest cieplejsza, jej gotowanie odbywa się łatwiej). Przeciwnie zaś, gdy <embrion kobiecy> znajdzie się poza matką, zbliża się szybko do kresu swojego rozwoju i do starości, ponieważ jest słaby".

${ }^{40}$ Aristoteles, De partibus animalium 5, 651b, thum. P. Siwek: Arystoteles, O częściach zwierzat, BKF 124, Warszawa 1977, 44.

${ }^{41}$ Por. Aristoteles, De generatione animalium I 18, 725b, Siwek, s. 40: „Dodajmy mimochodem, że nasienia nie ma we wczesnej młodości, w starości i w okresie choroby; w tym ostatnim przypadku nie ma go z powodu osłabienia organizmu; w starości dlatego, że organizm nie jest w stanie przegotować dostatecznej ilości pokarmu; w młodości wreszcie z powodu procesu rośnięcia, bo cały zapas pokarmu jest od razu zużyty".

${ }^{42}$ Por. Aristoteles, Problemata XXXI 14, 958b i 25, 959b, thum. L. Regner: Arystoteles, Zagadnienia przyrodnicze, BKF 136, Warszawa 1980, 336 i 339: „Suchość powoduje stwardnienie całej skóry, także źrenicy. Dlatego również starcy nie mają wzroku bystrego. U starców bowiem rogówka jest stwardniała i pomarszczona, wobec czego wzrok jest przyćmiony [...]. Krótkowidz i starzec obaj są dotknięci pewnym osłabieniem wzroku [...], albowiem człowiek stary nie jest władny ujrzeć jakiś przedmiot"; Aristoteles, De anima I 4, 408b, tłum. P. Siwek: Arystoteles, O duszy, BKF 96, Warszawa 1972, 23-24: „Gdyby starzec otrzymał dobre oko, widziałby również dobrze jak młodzieniec. Z czego wynika, że starość pochodzi nie od jakiejś ułomności duszy, lecz podmiotu, w którym ona przebywa". 
starszych $^{43}$, starczy marazm, melancholia i zniechęcenie do życia ${ }^{44}$, twardość i ziemistość włosów, które szczególnie bujnie rosną w chorobie i starości ${ }^{45}$, siwizna włosów, która jednak nie pochodzi tym razem $\mathrm{z}$ wysychania wilgoci w organizmie, ale z braku jej gotowania się oraz gnicia ${ }^{46}$, zagęszczenie brwi ${ }^{47}$, a także łysina ( $\varphi v \lambda \alpha \kappa \rho o ́ \tau \eta \varsigma)$, spowodowana niedostatecznością ciepłej wilgoci w głowie ${ }^{48}$, która jednak, zdaniem Arystotelesa, „nie dosięga człowieka zanim zaczął oddawać się czynnościom płciowym. Stąd też ani dziecko, ani kobieta, ani eunuch nigdy nie łysieje"

${ }^{43}$ Por. Aristoteles, Problemata XXXVIII 8, 967b, Regner, s. 368: „Ludzie starzejący się przyjmują ciemniejsze zabarwienie skóry [...]. Starość i psucie się są czymś jednym. Skoro krew, która wysycha, robi się ciemniejsza, przeto starsi słusznie powinni mieć zabarwienie skóry ciemniejsze".

${ }^{44}$ Por. Aristoteles, Problemata XXX 1, 955a, Regner, s. 322-323: „Starość bowiem jest beznadziejna, młodość natomiast pełna nadziei [...] młodzi jednak wieszają się częściej niż starcy. Starość bowiem osłabia gorąco, przy czym u nich jest to zjawisko naturalne i gorąco zanika samo przez się. Wielu zaś tych, u których gorąco wygasło nagle, sami zadają sobie śmierć [...]. Chłopcy również są w nastroju radośniejszym, starcy natomiast są bardziej zniechęceni, tamci bowiem są gorący, ci zaś chłodni: starość bowiem jest pewnym ochłodzeniem”.

${ }^{45}$ Por. Aristoteles, De generatione animalium 16, 745a, Siwek, s. 103: „Włosy w szczególności rosną w czasie chorób lub wtedy, gdy organizmy się starzeją i podupadają. A to dlatego, że w starości i chorobach mniej pożywienia się zużywa”; tamże V 4, 782b-785b, Siwek, s. 224-225: „Zwierzęta, które zawierają wielką ilość wilgoci, mają włosy proste, bo w ich włosach przesuwa się wilgoć nieprzerwanym strumieniem, a nie kropla za kroplą [...]. W miarę bowiem jak ciepło jest wypierane, wilgoć się ulatnia, a włosy wraz ze skórą stają się ziemiste i twarde [...] włosy twardnieją w miarę, jak w latach postępują ci, którzy je mają [...]. Z wiekiem bowiem skóra twardnieje i grubieje wskutek jej wysychania, a starość, jak wskazuje na to etymologia tego słowa, jest czymś ziemistym przez to, że straciła ciepło, a z nią wilgoć".

${ }^{46}$ Por. Aristoteles, Historia animalium III 11, 518a, thum. P. Siwek: Arystoteles, Zoologia, BKF 145, Warszawa 1982, 99: „Włosy zmieniają kolor w miarę, jak osobniki się starzeją: u człowieka bieleją [...] choć w bardzo wielu wypadkach siwizny włosy staja się białe. Fakt ten jasno wskazuje, że biały kolor włosów nie pochodzi od wyschnięcia - przeciwnie niż niektórzy utrzymują - bo nic nie zaczyna rosnąć, gdy jest w stanie suchym"; De generatione animalium V 4-5, 784b, Siwek, s. 228 i 231: „U wszystkich ludzi, których włosy mają z natury mało ciepła, a wilgoć, która wchodzi, jest zbyt obfita, ciepło własne nie jest w stanie dokonać gotowania i włosy zaczynają gnić pod wpływem ciepła obecnego w otoczeniu. Wszelkie gnicie pochodzi od ciepła, lecz nie od ciepła wrodzonego [...]. Siwizna jest wynikiem szczególnego rodzaju gnicia, a nie jak niektórzy sądzą, procesem wysuszania [...]. Siwizna nie jest formą wysuszenia, a włos nie bieleje w taki sam sposób, w jaki usycha trawa”.

${ }^{47}$ Por. Aristoteles, Historia animalium III 11, 518a, Siwek, s. 100: „W miarę, jak się niektórzy starzeją, ich brwi stają się tak gęste, że trzeba je obcinać. Pochodzi to stąd, że brwi znajdują się w miejscu, w którym schodzą się kości; otóż w starości te kości się rozsuwają i przepuszczają więcej wilgoci”.

${ }^{48}$ Por. Aristoteles, De generatione animalium V 3, 783b, Siwek, s. 225-226: „Łysina występuje u ludzi wyraźniej niż u jakichkolwiek innych zwierząt. Lecz i ona jest zjawiskiem ogólnym [...]. Przyczyną tego zjawiska jest niedostateczność wilgoci ciepłej, a własność te posiada w najwyższym stopniu wilgoć tłusta [...]. Nikt nie zaczyna łysieć, nim nie zazna stosunków płciowych. Wtedy także więcej łysieją ci, którzy są z natury do tego skłonniejsi [...]. Kobiety nie łysieją, bo ich natura zbliża się do natury dzieci [...]. Także eunuch nie łysieje, bo zmienił się w kobietę".

${ }^{49}$ Aristoteles, Historia animalium III 11, 518a, Siwek, s. 99-100. 
Celowo przedstawiliśmy szerzej poglądy Arystotelesa z konkretnymi jego wypowiedziami na temat starości, bo zawiera się w nich wiele medycznych skądinąd nieznanych myśli współczesnych mu hipokratyków, a osoba wielkiego filozofa przyczyniła się do ich upowszechnienia i oddziaływania. Poglądy te podzielali powszechnie, a nierzadko je w oparciu o własną praktykę poszerzali, również późniejsi przedchrześcijańscy hipokratycy, bazując nadal na starej teorii o wrodzonym cieple i wilgoci w organizmie oraz na metodzie mistrza przyjmującej za podstawę leczenia obserwację objawów dolegliwości, a później ich interpretację i wyciaganie terapeutycznych wniosków ${ }^{50}$. W odniesieniu do starości dostrzegali coraz więcej odmiennych jej przejawów i dolegliwości u płci - żeńskiej i męskiej. Najpierw za swym mistrzem przyjmowali, że kobiety stare są bardziej wysuszone niż młode, bo mają też mniej krwi ${ }^{51}$. Podstawowym przejawem ich starości jest zanik zdolności rozrodczych wyrażający się m.in. w zaniku miesiączki, zwiotczeniu piersi i narządów rodnych, częstym owrzodzeniu macicy i w ogóle dysfunkcji łona ${ }^{52}$. Starzeją się szybciej niż mężczyźni z powodu słabości swego ciała i sposobu życia, a teoretyczne uzasadnienie tego procesu odnajdywano w pojęciu starości jako wyziębianiu i wysuszaniu organizmu. One też z natury są zimniejsze od mężczyzn, co zauważał również Arystoteles, stosują mniej rozgrzewającą dietę, a tracą też wiele ciepła przez menstruację ${ }^{53}$. Również jednak i mężczyźni mają swoje starcze dolegliwości, m.in. urogenitalne związane $\mathrm{z}$ oziębianiem się organizmu, jak brak erekcji czy aspermia fizjologiczna ${ }^{54}$, czy też kłopoty z oddawaniem moczu, związane $\mathrm{z}$ niewydolnością nerek ${ }^{55}$. Wśród innych dolegliwości dotyczących już obu płci, wymienianych w pismach Corpus Hippocraticum, były różnego rodzaju

${ }^{50}$ Por. W.D. Smith, The genuine Hippocrates and his theory of therapy, w: Aspetti della terapia nel „Corpus Hippocraticum”. Atti del IXe Colloque International Hippocratique (Pisa, 25-29 IX 1996), ed. I. Garofalo, Firenze 1999, 107-118; J. Barański, Hipokratesa koncepcje sztuki leczenia, „Nauki Humanistyczne” 6 (2001) 97-102.

${ }^{51}$ Por. Hippocrates, De mulierum affectibus II 111, ed. Littré VIII 238: „Stare kobiety są bardziej suche i uboższe w krew"; De natura muliebri 1, Littré VII 312; Aphorismi II 53, ed. Littré IV 484; P. Manuli, Fisiologia e patologia del femminile negli scritti ipocratici dell'antica ginecologia greca, w: Hippocratica, ed. M.D. Grmek, Paris 1980, 393-408; taż, Donne mascoline, femmine sterili, virgini perpetue. La ginecologia greca tra Ippocrate e Sorano, w: Madre materia. Sociologia e biologia della donna greca, ed. S. Campese - P. Manuli - G. Sissa, Torino 1983, 149-192; H. King, Hippocrates' woman: reading the female body in ancient Greece, London 1998; V.P. Comiti, Variations de la thérapeutique en fonction du sexe du patient dans la Collection Hippocratique, w: Aspetti della terapia nel ,, Corpus Hippocraticum”, s. 125-137.

${ }^{52}$ Por. Hippocrates, De mulierum affectibus I 63; II 110; II 127; II 137; De natura muliebri 3; G. Pisi, La medicina greca antica, s. 463-464.

${ }^{53}$ Por. Hippocrates, De septimestri partu 9; De alimento I 33; Prorrheticon II 41; De diaeta I 25, 1.

${ }^{54}$ Por. Hippocrates, Prorrheticon II 41; De diaeta I 25, 1.

55 Por. Hippocrates, Coa praesapia 578, Littré V 718; Byl, La vieillesse dans le Corpus Hippocratique, s. 89 i 93. 
starcze atrofie mięśniowe ${ }^{56}$ i reumatyzmy ${ }^{57}$ wynikające $\mathrm{z}$ wyziębiania się i wysuszania organizmu, częsta i nieuleczalna w starości podagra ${ }^{58}$, różnego rodzaju wrzody i zwyrodnienia ${ }^{59}$, biegunki ${ }^{60}$, nieodłączne od starości epilepsje ${ }^{61}$, czy bóle lub zawroty głowy ${ }^{62}$.

$\mathrm{Na}$ zmniejszenie powyższych dolegliwości wieku starczego również późniejsi przedchrześcijańscy hipokratycy proponowali odpowiednią terapię, która skupiała się głównie na dwóch dziedzinach - odpowiedniej diecie alimentarnej oraz ćwiczeniach fizycznych, obejmujących różnego rodzaju masaże. Nic też dziwnego, że spod pióra ówczesnych hipokratyków wyszło szereg poradników dotyczących zdrowej diety, a i samemu Hipokratesowi przypisano ich

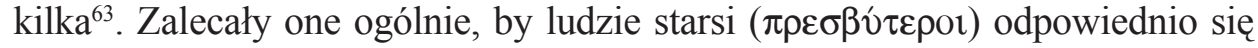
odżywiali, stosując raczej dietę suchą, która by ich rozgrzewała i przeciwdziałała wyziębianiu organizmu oraz przywracała w nim równowagę ${ }^{64}$. Starano się też w nich wypracować pojęcie tzw. ,potrzeby żywnościowej”, odpowiadającej danemu wiekowi: „Odpowiednią porcją żywności dla osób starszych jest taka, która by utrzymywała ich przy życiu”" ${ }^{5}$, a pokarm dla nich winien być tak przygotowany, by nie wywoływał u nich zaburzeń trawiennych ${ }^{66}$. Drugim zasadniczym terapeutycznym środkiem na starość, zalecanym przez hipokratyków, łagodzącym jej dolegliwości oraz zapewniającym względnie sprawne i spokojne życie, były, jak wspominaliśmy, ruch i różnego rodzaju ćwiczenia fizyczne, bo tylko one i aktywne używanie poszczególnych części ciała, mogą zapewnić, nawet w starości, należytą sprawność ${ }^{67}$. Obok tych, już wówczas, niektóre pisma

\footnotetext{
${ }^{56}$ Por. Hippocrates, Prorrheticon II 39; II 40-41, Littré 68-70.

${ }^{57}$ Por. tamże II 7, Littré IX 26; Byl, La vieillesse dans le Corpus Hippocratique, s. 94; tenże, Rheumatism and gout in the Corpus Hippocraticum, AC 57 (1988) 89-102.

${ }^{58}$ Por. Hippocrates, Prorrheticon II 7.

${ }^{59}$ Por. tamże 11, Littré IX 30.

${ }^{60}$ Por. tamże 23, Littré IX 52.

${ }^{61}$ Por. tamże 9, Littré IX 28; De morbo sacro, Littre VI 352-396; Byl, La vieillesse dans le Corpus Hippocratique, s. 90.

${ }^{62}$ Por. Hippocrates, Prorrheticon 30, Littré IX 62; Pisi, La medicina greca antica, s. 466.

${ }^{63}$ Por. Hippocrates, De diaeta acutorum, ed. Littré II 394-528; De diaeta in morbis acutis, ed. Littré II 224-376 lub ed. Jones II 62-125; Vectiarius, ed. Littré IV 340-394; De diaeta salubri, ed. Littré VI 72-86 lub ed. Jones IV 44-59; De diaeta I-IV, ed. Littré VI 466-662 lub ed. Jones IV 224447; De alimento, ed. Littré IX 98-120 lub ed. Jones I 333-361.

${ }^{64}$ Por. Hippocrates, De diaeta I 2; I 32, 4; Byl, La vieilesse dans le Corpus Hippocratique, s. 89-90; Pisi, La medicina greca antica, s. 459, n. 52-53 i s. 467.

${ }^{65}$ Por. Hippocrates, De alimento 34, ed. Littré IX 110 lub ed. Jones I 354.

${ }^{66}$ Tamże 41, ed. Littré IX 112 lub ed. Jones I 356.

${ }^{67}$ Por. Hippocrates, De articulis 58, ed. Littré IV 249 lub ed. Jones III 334: „Wszystkie części ciała, które są po to, by je używać, jeżeli są wykorzystywane odpowiednio i przez ćwiczenia utrzymywane w aktywności, do której każda z nich jest przeznaczona, wtedy trzymają się zdrowo oraz rozwijają się i starzeją dobrze; jeśli natomiast nie są używane i pozostają w spoczynku, stają się chorowite, nie rozwijają się i szybko się starzeją".
} 
hipokratyków proponowały również pewne środki kosmetyczne, niwelujące, zwłaszcza u kobiet, szpetne defekty starości, jak zmarszczki ${ }^{68}$ czy łysinę ${ }^{69}$.

Spośród wielu ówczesnych hipokratyków, których pisma zaginęły lub przypisano je Hipokratesowi, wypada tu wymienić przynajmniej trzech najwybitniejszych, którzy zajmowali się starością, choć ich pisma zachowały się tylko fragmentarycznie, cytowane przez innych. Należy do nich m.in. żyjący w IV wieku prz. Chr. Diokles z Karystos, jeden z najsławniejszych lekarzy starożytności, nazywany drugim lub młodszym Hipokratesem ${ }^{70}$, który pierwszy zebrał pisma swego imiennika, a później był często cytowany przez Oribazjusza, Galena, Soranusa Makrobiusza. Był zwolennikiem teorii dziesięciu 7-letnich okresów życia ludzkiego, uważając rok 70. za jego kres, a rok 60., według Soranosa, za najdalszą granicę obecności miesiączki u kobiet, czyli początek ich starości ${ }^{71}$. Ciekawe są też jego zalecenia dietetyczne dla osób starszych, zawarte w ocalałym fragmencie jego pisma $O$ diecie, cytowanym przez późniejszego Oribazjusza ${ }^{72}$. Podając w nim porządek dnia, dotyczący higieny ciała, diety oraz organizacji pracy i odpoczynku wolnego człowieka, dostosowany do wieku, tak żeby zachował on zdrowie w każdym czasie, osobom starszym zalecał po zbudzeniu się rano umiarkowaną aktywność fizyczną: przed ćwiczeniami fizycznymi doradzał lekkie namaszczenie oliwą nasłonecznionych miejsc ciała oraz wizytę w łaźni; praktyka automasażu winna, jego zdaniem, zastąpić właściwą wyczerpującą przedpołudniową gimnastykę fizyczną. Po śniadaniu i sjeście doradzał dalsze lekkie masaże, namaszczanie oliwą i delikatne obmywanie ciepłą wodą, ale bez moczenia głowy, a zbytnie obmywanie wodą zastępować raczej masażami połączonymi z nacieraniem oliwą zmieszaną z wodą (w lecie) lub winem (w zimie); doradzał także umiarkowaną aktywność seksualną, dostosowaną do wieku i kondycji fizycznej ${ }^{73}$.

Szereg uwag na temat starości spotykamy również w zachowanych fragmentach pism medycznych nieco młodszego od Dioklesa niejakiego Proksa-

\footnotetext{
${ }^{68}$ Por. Hippocrates, De morbis mulierum II 188, ed. Littré VIII 368.

${ }^{69}$ Por. tamże II 189, ed. Littré VIII 370.

${ }^{70}$ Por. Vindicianus, c. 2: „Diocles, sectator Hippocratis, quem Athenienses iuniorem Hippocraten vocaverunt"; Plinius, Historia naturalis XXVI 10: „qui secundus aetate famaque exstitit”; M. Wellmann, Diokles von Karystos, RE V/1, 802-812; L. Edelstein - W. Jaeger, Diokles von Karystos, AJPh 61 (1940) 483-489 = Ancient Medicine, Baltimore 1967, 145-152; Pisi, La medicina greca antica, s. 477-478, spec. n. 133.

${ }^{71}$ Por. Soranus, Gynaecia I 4, 20 (= fragm. 171 Wellmann), thum. J. Lachs: Ginekologia Soranusa z Efezu, „Roczniki Towarzystwa Przyjaciół Nauk Poznańskiego” 28 (1901) 38: „Diokles utrzymuje, że miesiączka trwa aż do sześćdziesiątego roku, że jest najsamprzód skąpa, następnie doszedłszy do szczytu pozostaje jakiś czas w tym samym nasileniu, po czym znowu się zmniejsza, aż wreszcie całkiem zanika"; zob. D.W. Amundsen - C.J. Diers, The age of menopause in Classical Greece and Rome, „Human Biology” 42 (1970) 79-86, spec. 82.

${ }^{72}$ Por. Oribasius III 168nn (fragm. 141 Wellmann); zob. Fragmenta apud Oribasium, w: Corpus Medicorum Graecorum (= CMG), vol. VI 1, 1 i VI 2, 1-2; VI 6, 3.

${ }^{73}$ Por. Pisi, La medicina greca antica, s. 478.
} 
gorasa z Kos (ok. 300 prz. Chr.) $)^{74}$, autora kilku traktatów znanych nam tylko

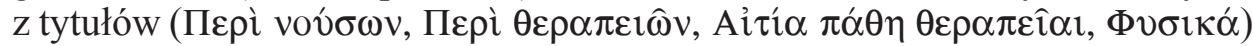
cytowanych przez Galena, Rufusa, Atenajosa i Oribazjusza, który w swojej terapii, zwłaszcza dietetycznej, podkreślał znaczenie postu oraz leczące oddziaływanie słodkiego wina i ciepłej wody, uwzględniając przy tym również pozbawiony wrodzonego ciepła starczy wiek człowieka; starość wiązał tradycyjnie z wyziębieniem i wyczerpaniem organizmu, czego objawami miały być często występujące $\mathrm{w}$ nim niepohamowany apetyt i krzepnięcie krwi w żyłach, występujące zwłaszcza w zimie. Ze względu na pojawiające się w tym wieku częste niebezpieczeństwo zapalenia płuc, ludzie starsi winni być w tym czasie otaczani specjalną opieką, nie należy u nich praktykować upuszczania krwi, często stosować napary z jęczmienia, a w wypadku zbytniej obfitości płynów w żyłach, unikać oczyszczania ich czarnym ciemiernikiem ${ }^{75}$.

Wreszcie dla Herofilosa z Chalcedonu, ucznia Proksagorasa, starość była trzecim stanem każdego organizmu, nie będącym ani zdrowiem, ani chorobą, ale zwykłą naturalnością ${ }^{76}$. W swoich zachowanych również tylko

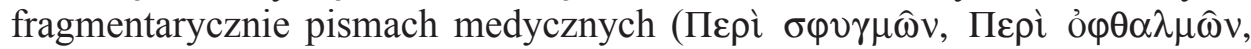
$\Theta \varepsilon \rho \alpha \pi \varepsilon v \tau \imath \kappa \eta ̀ ~ \pi \rho \alpha \gamma \mu \alpha \gamma \mu \alpha \tau \varepsilon i \alpha, \Delta \imath \alpha \imath \tau \eta \tau \imath \kappa o ́ v)$ wyznawał, jak poświadcza Sekstus Empiryk ${ }^{77}$, zasadę, że mądrość i sztuka, władza i bogactwo nic nie znaczą, jeśli brakuje zdrowia. Uważany jest za twórcę teorii o pulsie: również ocenę stopnia starości wyprowadzał z jakości pulsu jako znaku diagnostycznego; puls według niego jest różny (ilość, miara, szybkość, siła, rytm) w każdym wieku (dziecięctwo, młodość, dojrzałość, starość) i jest cechą charakterystyczną i rozpoznawczą z której należy wyprowadzać praktyczne wnioski o stanie zdrowia, zwłaszcza w starości, będącej wyziębieniem organizmu ${ }^{78}$.

Z powyższych uwag wynika, że medycy okresu przedchrześcijańskiego, głównie hipokratycy, których pisma zachowały się w większości tylko fragmentarycznie, nie posiadali jednoznacznej oceny starości, nie poświęcili jej żadnego specjalnego traktatu medycznego, który leczyłby jej słabości, ale tylko okolicznościowo ukazywali zarówno jej walory, jak i ułomności, wskazując przy tym różnoraką jej terapię, która polegała głównie na diecie alimentarnej i ruchu.

${ }^{74}$ Por. F. Steckerl, The fragments of Proxagoras of Cos and his School, Leiden 1958; K. Bardong, Proxagoras von Kos, RE XXII/2 1104-1110.

${ }^{75}$ Por. Galenus, De naturalibus facultatibus II 8, 182 Loeb = fragm. 18, CMG vol. V 2, 1, s. 54; zob. Pisi, La medicina greca antica, s. 478-479.

${ }^{76}$ Por. H. von Staden, Herophilus. The art of medicina in early Alexandria, Cambridge 1989; Gossen, Herophilus von Chalkedon, RE VIII/1 1104-1110.

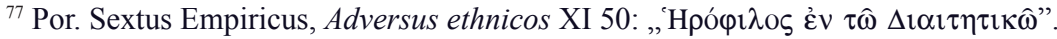

${ }^{78}$ Pisi, La medicina greca antica, s. 479-480. 


\section{W OKRESIE WCZESNOCHRZEŚCIJAŃSKIM}

Bardziej nas zapewne zainteresuje problem, jak wyglądała medyczna troska o ludzi starszych w okresie wczesnochrześcijańskim - dobie Ojców Kościoła (I-VIII wiek). Oni bowiem ucząc o przykazaniu miłości bliźniego i jego praktykowaniu w stosunku do chorych i słabych, musieli z tym problemem stykać się, jak i z literaturą medyczną na temat geriatrii, a może i sami z niej korzystać ${ }^{79}$. Otóż źródła starożytne wymieniają nam wielu medyków, encyklopedystów lub przyrodników znanych często tylko z nazwiska, zarówno w sferze języka greckiego (m.in. Apoloniusz z City lub Pergamonu - I w., Kasjusz -Areteusz z Kapadocji $^{80}$ - I w., Dioskorides - I w., Herocjan - I w., Sewer Iatrosofista - I w., Rufus z Efezu ${ }^{81}$ - I/II w., Galen - II w., Marcelin - II w., Filumen - II w., Kasjusz - II/III w., Oribazjusz z Pergamonu - IV w., Paulus z Eginy - VI w., Aecjusz VI w., Palladiusz - VI w., Aleksander z Tralles - VI w., anonimowy autor traktatu De natura hominis oraz pisma De diaeta), jak i łacińskiego (m.in. Aulus Korneliusz Celsus $^{82}$ - I w., Skriboniusz Largus - I w., Pliniusz Starszy - I w., Serenus Sammonik -III/IV w., Windycjan - IV w., anonimowy autor Medicina Plinii IV w., autor De herba vettonica Antoni Musa - IV w., Teodor Priscjan - IV w., Marcellus Empiryk - IV/V w., Celiusz Aurelian - V w., Kasjusz Feliks - V w. $)^{83}$, żaden z nich jednak nie napisał specjalnego traktatu medycznego poświęconego

${ }^{79}$ Por. m.in. St. D'Irsay, Christian medicine and science in the third century, ,Journal of Religion” 10 (1929) 514-544; J. Cuesta, La antropologia y la medicina pastoral de San Gregorio de Nisa, Madrid 1946; G.B. Ferngren, The organisation of the care of the sick in early Christianity, w: Actes/ Proceedings of the XXX International Congress of the history of Medicine, ed. H. Schadewaldt K.H. Leven, Düsseldorf 1988, 192-198; J.C. Iarchet, Thérapeutique des maladies mentales. L'expérience de l'Orient Chrétien des premiers siècles, Paris 1992; G.B. Ferngren - D.W. Amundsen, Medicine and Christianity in the Roman Empire. Compatibilities and tensions, ANRW 37, 3, Berlin - New York 1996, 2957-2980; U. Mattioli, Assistenza e cura dei malati nell'antichità cristiana, w: Cultura e promozione umana. La cura del corpo e dello spirito nell' antichità classica e nei primi secoli cristiani. Un magistero ancora attuale? Atti del Convegno II Internationale (Troina, 29 X - 1 XI 1997), ed. E. Dal Covolo - I. Giannetto, Troina 1998, 247-278; I. Mazzini, La letteratura cristiana antica e la medicina, I: Saggio di indagine su ,, Realien” e linguaggio medici nella letteratura cristiana, „Les Etudes Classiques” 70 (2002) 353-372 (Literatura); 71 (2003) 241-261; T. Heyne, Were second-century Christians 'preoccupied' with physical healing and the Asclepian cult?, StPatr 44 (2010) 63-70..

${ }^{80}$ Por. F. Kudlien, Untersuchungen zu Aretaios von Kappadokien, Mainz 1963.

${ }^{81}$ Por. A. Sideras, Rufus von Ephesos und sein Werk, ANRW 37.2, New York - Berlin 1994, 1076-1253.

82 Por. K. Morawski, Literatura rzymska. Od Augusta do czasów Hadriana, Kraków 1919, 62-65; M. Cytowska - H. Szelest, Literatura rzymska. Okres cesarstwa, Warszawa 1992, 63 (Aulus Korneliusz Celsus).

${ }^{83}$ Por. I. Mazzini, Per un lessico del latino medico-antico: consuntivo, problemi e prospettive, w: Atti del I. Seminario di Studi Lessici Tecnici Greci e Latini, ed. P. Radici Colace - K. Caccamo Caltabiano, Messina 1991, 243-255; I. Mazzini, La geriatria di epoca romana, w: Senectus. La vecchiaia nel mondo classico, ed. U. Mattioli, vol. 2: Roma, Bologna 1995, 340. 
starości, a obszerniejsze wypowiedzi na temat jej objawów czy terapii spotykamy tylko u kilku w ich pismach medycznych o innej problematyce; należą zaś do nich: Celsus, Areteusz, Oribazjusz, Celiusz Aurelian, Aecjusz, Paulus z Eginy, anonimowy autor De natura hominis, a przede wszystkim Galen z Pergamonu (129-199), filozof i przyboczny lekarz cesarzy Marka Aureliusza, Lucjusza Werusa i Kommodusa, gorący zwolennik tradycji Hipokratesa ${ }^{84}$; ten ostatni czynił to głównie w trzech swoich traktatach: De sanitate tuenda (O strzeżeniu zdrowia $)^{85}$, De marcore $(\mathrm{O} \text { marazmie })^{86} \mathrm{i}$ De temperamentis $(\mathrm{O} \text { temperamentach })^{87}$, które też będą zasadniczym źródłem dalszej analizy.

Są to pierwsze starożytne traktaty specjalne, poświęcone przynajmniej w części starości i jej terapii, jakie do nas dotarły, zwłaszcza V księga De sanitate tuenda i De marcore. Również po Galenie nie spotykamy takowych, poza specjalnymi nieraz mniej lub więcej obszernymi rozdziałami w encyklopediach medycznych Oribazjusza, Aecjusza, czy Paulusa z Eginy, które jednak nie zawierają w zasadzie nic nowego w porównaniu z Galenem, ale są streszczeniami jego wypowiedzi, lub niekiedy dosłownymi z nich wyciagami, jak np. w przypadku Paulusa z Eginy, autora obszernego Epitomae medicae libri septem ${ }^{88}$, chociaż problem diety u ludzi starszych był przed Galenem medycznie, oprócz niektórych hipokratyków, poruszany przez takich autorów, jak na przykład Artoriusz Asklepiades (I w. prz. Chr. ${ }^{89}$, Rufus z Efezu ${ }^{90}$, czy też nazywany przez Galena filozofem uczeń Archigenesa Filip z Cezarei ${ }^{91}$.

Tak więc Galenowa V księga traktatu De sanitate tuenda i De marcore są jedynymi znanymi nam dotąd specjalistycznymi starożytnymi monografiami, poświęconymi starości i jej terapii. Pierwsza z nich traktuje najpierw ogólnie o naturze starości oraz o nieuniknionym przechodzeniu organizmu do stanu

${ }^{84}$ Por. S. Byl, La gerontologie de Galien, w: History and philosophy of the life sciences, Napoli 1988, 73-94; W. Klinger, Galena pismo „,Jak lekarz doskonaty jest zarazem filozofem”, Poznań 1938; R.E. Siegel, Galen's system of Physiology and medicine, Basel - New York 1970; A. Bednarczyk, Galen. Główne kategorie systemu filozoficzno-lekarskiego, Warszawa 1995.

${ }^{85}$ Por. Galenus, De sanitate tuenda libri VI, ed. C.G. Kühn: Claudi Galeni opera omnia, vol. I-VI, Leipzig 1821-1833 (repr. Hildesheim 1964-1965) lub ed. K. Koch: Galeni de sanitate tuenda libri I-VI (= CMG, vol. V 4, 2, Leipzig 1923), 3-198.

${ }^{86}$ Por. Galenus, De marcore, ed. Kühn: Claudi Galeni opera omnia, vol. VII, Leipzig 1821 (repr. Hildesheim 1964), 666-704.

${ }^{87}$ Por. Galenus, De temperamentis libri III, ed. G. Helmreich: Galeni de temperamentis, Leipzig 1904, Teubner (repr. Stuttgart 1969), 1-115.

${ }^{88}$ Por. Paulus Aegineta, Epitomae medicae libri septem, ed. J.L. Heiberg, CMG, vol. IX/1, 3-388 i IX/2, 5-411.

${ }^{89}$ Por. Asclepiades, Praecepta salubria, w: Fragmenta apud Galenum, ed. G. Helmreich, vol. $1,340-341$.

${ }^{90}$ Por. J. Ilberg, Rufus von Ephesos. Ein griechischer Arzt in traianischer Zeit, „Abhandlungen der Sächsi. Akad. Wiss. Phil. Hist. Klasse" 41 (1930) 48.

${ }^{91}$ Por. C. Theocharides, Galen on Marasmus, „J. Hist. Med.” 26 (1971) 369-390; Philippus, Fragmentum apud Galenum, CMG, vol. IX/2, 317. 
oziębiania się i wysuszania, o nieodzownym zmniejszaniu i indywidualizowaniu diety, o zdrowym życiu w młodości i starości, opisując $\mathrm{w}$ detalach dietę człowieka starego - masaże, ćwiczenia oraz żywienie, przy którym podaje konkretne wskazówki odnośnie spożywania wina, chleba, mleka czy owoców, by całość zakończyć ogólnym podsumowaniem ${ }^{92}$. W drugim zaś traktacie Пepi $\mu \alpha \rho \alpha \sigma \mu \mathrm{o}$ (terminu tego użył po raz pierwszy właśnie Galen nawiązując do użytego przez Arystotelesa terminu $\mu \alpha ́$ ó $\alpha v \sigma ı \varsigma$ na oznaczenie procesu starzenia się) ${ }^{93}$ najpierw jest mowa o etiologii i fizjopatologii starości (cieple wrodzonym i wysuszaniu organizmu) oraz jej nieuchronności w przeciwieństwie do marazmu pochodzącego z przyczyn nienaturalnych (np. z gorączki lub złego żywienia się); marazm starości prowadzi, jego zdaniem, do wysuszania serca czy żołądka i dlatego jest nieuleczalny. Galen w tych traktatach czuje po raz pierwszy potrzebę istnienia dyscypliny medycznej, która w sposób praktyczny i teoretyczny zajmowałaby się starością - stanem nieuchronnym między zdrowiem a chorobą ${ }^{94}$. Według Galena, ten lekarz będzie dobrym geriatrą ( $\alpha \gamma \alpha \theta$ òs

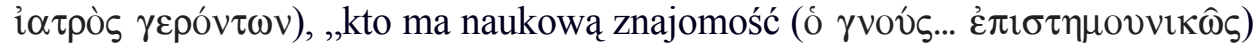
stanu starego człowieka, jego wysuszenia i wyziębienia, a także, który poznał, jakie są bezpośrednie przyczyny nawilżania i kaloryczności”95.

$\mathrm{Na}$ wstępie tu jednak trzeba zaznaczyć, że ogół medycznych poglądów okresu wczesnochrześcijańskiego na temat starości i jej terapii była kontynuacją wcześniejszej tradycji hipokratejskiej, często ją tylko poszerzano lub uzupełniano, a rzadko zmieniano lub odrzucano. Nadal przyjmowano jako niezaprzeczalną opinio communis, że człowiek stary jest zimny, odrzucano natomiast przekonanie niektórych hipokratyków ${ }^{96}$, że jest on również bardzo wilgotny, bo oprócz tego, że ma wrodzony „fluid witalny” w postaci limfy, jest często wówczas przepełniony różnego rodzaju wydzielinami (np. katarem, śluzem, ropa, flegmą). Tak i Galen zwalczał przekonanie, że jest on w jakikolwiek sposób wilgotny ucząc, że każdy człowiek stary jest zawsze suchy ${ }^{97}$. Od-

${ }^{92}$ Por. Wörle, Studien zur Theorie der antiken Gesundheitslehre, Stuttgart 1990, 212-248, spec. 235-238; J. Moszyński, Galenus: De victu attenuante, Archiwum Historii Medycyny” 45 (1982) 61-75.

${ }^{93}$ Por. H.G. Liddell - R. Scott, A Greek-English Lexicon, Oxford 1966, 1080; Aristoteles, De iuventute 469b 22; Respublica 474b 20; Meteorologica 361b 21, 372b 19.

${ }^{94}$ Por. Galenus, De sanitate tuenda V 4, ed. Kühn VI 53O: „Mówić te lub inne rzeczy jest bardzo łatwo, ale zająć się konkretnie ratowaniem zdrowia ludzi starych jest bardzo trudne, tak jak zajmowanie się zdrowiem rekonwalescentów. Tę drugą część sztuki lekarskiej młodsi lekarze

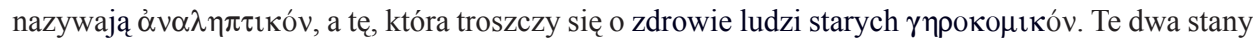
[starego i rekonwalescenta] nie są pełnym zdrowiem, ale w jakiś sposób stanami pośrednimi między zdrowiem a chorobą"; tamże V 9 i VI 2, Kühn VI 357 i 389; De marcore 5, Kühn VII 682.

${ }^{95}$ De sanitate tuenda V 10, Kühn VI 358; podobnie Aetius, Iatricorum liber IV 3, CMG VIII/1 359.

96 Tak przyjmowały niektóre, zwłaszcza anonimowe, traktaty, np. De morbis I, De natura hominis, De salubri diaeta; por. S. Byl, La gerontologie de Galien, s. 88-90; Pisi, La medicina greca antica, s. 460-461; Mazzini, La geriatria di epoca romana, s. 342; J. Jouanna, Sur les traces d'Hippocrate de Cos, w: Médecine antique, ed. P. Demont, Amiens 1991, 7-34.

${ }^{97}$ Por. Galenus, De temperamentis II 1, Kühn I 580-582: „Dlaczego niektórzy słynni lekarze 
różnia przy tym wilgotność zewnętrzną i akcydentalną od wilgotności organicznej twierdząc, że każdy człowiek stary jest wysuszony i wyziębiony, którym to poglądem wywarł zdecydowany wpływ na późniejszych medyków ${ }^{98}$, którzy odtąd przestali na ogół przyjmować wilgotność starego człowieka. On również sprecyzował samą dynamikę procesu wyziębiania i wysuszania się człowieka z wiekiem ${ }^{99}$. Medycy okresu patrystycznego znali również i przyjmowali wcześniejsze podziały życia ludzkiego na następujące po sobie okresy (co często przejmowali od nich i Ojcowie Kościoła w swoich pismach lub homiliach), zwłaszcza czwórkowy na podobieństwo czterech płynów w organizmie lub czterech pór roku, ale także siódemkowy, w zależności od potrzeb ${ }^{100}$. Podobnie również, jak wcześniejsi hipokratycy, traktowali starość jako stan jakościowy, a nie ilościowy: nie liczba lat czyni człowieka starym, ale pewne związane $\mathrm{z}$ wiekiem cechy psychiczno-fizyczne ${ }^{101}$. Tak również m.in. czynił Galen, który wyróżniał w starości trzy okresy, nie tyle w oparciu o liczbę lat, ile w oparciu o rodzaj i aktywność życia, jakie osoba podeszła wiekiem jest w stanie prowadzić: starzy-zieloni to ci, którzy zdolni są jeszcze prowadzić działalność polityczną; starcy to ci, których zadowala częsta kapiel, jedzenie

mówili o wilgotnej starości? Może byli myleni przez obfitość wydzielin? Oczy bowiem ludzi starych łzawią się, ich nos jest pełen śluzu, w ustach nadmiar śliny, często także kaszlą i plują śluzem kataru dowodząc, że ich płuca pełne są takiej wydzieliny; także ich brzuch jest wypełniony flegmą, a każdy z ich członków zdaje się być wilgotny; żaden jednak z tych objawów nie sprzeciwia się temu, że ciało ludzi starych jest suche. Zauważasz bowiem faktycznie, że ich nerwy, tętnice, żyły, błony i skóra ich organów są o wiele bardziej suche niż wcześniej, tylko że flegmatyczna i omszała wilgoć pokrywa je wewnątrz i zewnątrz. Każdy ich organ jest bardziej suchy niż w okresie poprzednim, ponieważ nie jest dokarmiany, a także z powodu braku ciepła... Człowiek stary jest więc wilgotny nie przez swoje organy, ale przez swoje wydzieliny, a jest suchy nie z braku swoich wydzielin, ale organów, ponieważ to one są tymi, których naturalne funkcje określają życie starego człowieka, i z powodu tych właśnie organów człowiek stary jest suchy, tak jak w okresie dziecięctwa był wilgotny; starość w zasadzie jest wiekiem suchym; zob. też Galenus, In Hippocratis opus de salubri victus ratione commentarius 7, Kühn XV 185-190; De sanitate tuenda V 8, Kühn VI 349; De marcore 3, Kühn VII 672; Mazzini, La geriatria di epoca romana, s. 348.

${ }^{98}$ Później suchości starego człowieka dowodzili podobnie m.in. Ps-Galenus, Definitiones medicae 4; Oribasius, Collectiones medicae XXI 3; Aetius, Iatricorum liber V 93; IX 34.

${ }_{99}$ Por. Galenus, De sanitate tuenda I 2, Kühn VI 4; V 9, Kühn VI 356.

${ }^{100}$ Por. Marcellinus, De pulsibus 352-354, ed. H. Schöne, Basel 1907: „Niektórzy dzielą [życie ludzkie] na cztery okresy: dziecko, młodzieniec, człowiek w kwiecie wieku i starzec [ $\pi \alpha \hat{\imath} \delta \alpha, \mu \varepsilon \rho o ́ k \kappa ı v$,

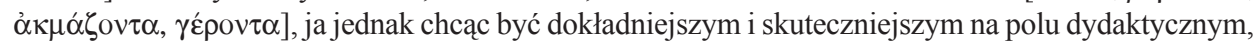
nie na cztery, ale na siedem okresów dzielę ludzkie życie i puls, jak to czynił Hipokrates w De septimanis...: niemowlę, dziecko, młodzieniec, człowiek w kwiecie wieku, stary, starzec i czcigodny"

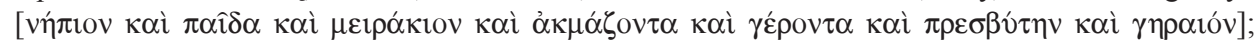
zob. Mazzini, La geriatria di epoca romana, s. 343.

101 Por. G. Pisi, La medicina greca antica, s. 453; S. Byl, La vieillesse dans le Corpus Hippocratique, s. 86; zob. Księgę Mąrości (II w. prz. Chr.) 4, 8: „Starość czcigodna jest, nie mierzy się jej liczbą lat". 
i spokojny sen; starcy zgrzybiali to ci, którzy nie znoszą częstej kąpieli ${ }^{102}$; gdzie indziej zaś dodawał, że nie jest możliwe określanie tych okresów tylko w oparciu o liczbę lat ${ }^{103}$. Podobnie na trzy okresy, ale w oparciu o puls,

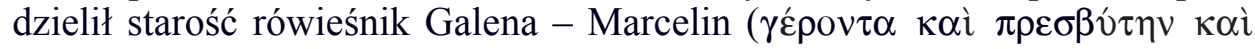
$\gamma \eta \rho \propto \imath o ́ v){ }^{104}$. Zdarzało się jednak, że i w tym okresie (podobnie jak i w okresie przedchrześcijańskim) określano starość liczbą lat, czyli ilościowo: tak m.in. czynił Aecjusz, który kobiety przekraczające 50 lat nazywał $\pi \rho \varepsilon \sigma \beta \hat{\tau} \tau \iota \delta \eta \varsigma$ (ze względu na menopauzę) ${ }^{105}$, tak anonimowy autor traktatu De natura hominis,

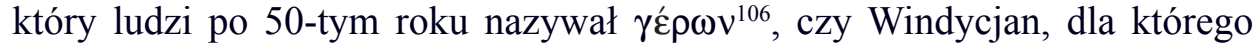
starość zaczynała się już od 42 roku życia ${ }^{107}$.

Medycy okresu wczesnochrześcijańskiego dostrzegają także i opisują już więcej, niż wcześniejsi hipokratycy, negatywnych symptomów i ułomności wieku starczego, zarówno fizycznych, jak i psychicznych. Obok tych wymienionych sumarycznie przez Hipokratesa ${ }^{108}$, które sami teraz często komentują i poszerzają ${ }^{109}$, mówią o starczych chorobach układu oddechowego i moczowego $^{110}$, o chorobach oczu, uszu oraz różnego rodzaju cherlactwach i spa-

${ }^{102}$ Por. Galenus, De sanitate tuenda V 12, Kühn VI 379-380: „Ludzie pierwszej części [starości]

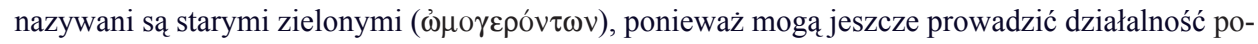
lityczną; druga jej część to ta, o której się mówi: «kiedy się wykąpali i najedli, śpią spokojnie». Ta nie przystoi trzeciej części [starości], w której, jak powiedziałem, znajdował się gramatyk Telefos, który mył się tylko dwa lub trzy razy na miesiąc; ci, którzy znajdują się w tym okresie, nie cierpią częstej kąpieli. Ten, który osiągnął ten okres, nazywany jest zgrzybiałym starcem ( $\pi \varepsilon ́ \mu \pi \lambda \circ v)$ ”.

${ }^{103}$ Por. tamże VI 2, Kühn VI 387.

${ }^{104}$ Por. wyżej n. 99.

${ }^{105}$ Por. Aetius, Iatricorum liber XVI 50, ed. S. Zervos: Gynaekologie des Aetios, Leipzig 1901; J. Lachs, Ginekologia Galena, Kraków 1902; D. Nickel, Untersuchungen zur Embryologie Galens, Berlin 1989.

${ }^{106}$ Por. De natura hominis I 6, ed. J.L. Ideler: Physici et medici Graeci minores, vol. 1, Berlin 1841, repr. Amsterdam 1963, 303-304.

${ }^{107}$ Por. Vindicianus, Epistula ad Pentadium; Mazzini, La geriatria di epoca romana, s. 343 i 350.

${ }^{108}$ Por. wyżej n. 21; zob też Byl, La vieillesse dans le Corpus Hippocratique, s. 93-95; Pisi, La medicina greca antica, s. 463-464.

${ }^{109}$ Por. Celsus, De medicina II 1, 22-23, ed. W.G. Specer, vol. 1, Cambridge - London 1960 Loeb, 96: „In senectute spiritus et urinae difficultas, gravedo, articulorum et renum dolores, nervorum resolutiones, malus corporis habitus ( $\kappa \alpha \chi \varepsilon \xi i \alpha \nu$ Graeci appellant), nocturnae vigiliae, vitia longiora aurium, oculorum, etiam narium, praecipueque soluta alvus, et quae secuntur hanc, tormina vel levitas intestinorum ceteraque ventris fusi mala. Praeter haec graciles tabes, deiectiones, destillationes, item viscerum et laterum dolores fatigant. Obesi plerumque acutis morbis et difficultate spirandi strangulantur, subitoque saepe moriuntur; quod in corpore tenuiore vix evenit"; Galenus, In Hippocratis aphorismos III 31 commentarii, Kühn XVIIB 648-651; De placitis Hippocratis et Platonis 8, 6, Kühn V 696.

${ }^{110}$ Por. Celsus, De medicina VII 26, 1, ed. Spencer vol. III 424: „Res vero interdum cogit emoliri manu urinam, cum illa non redditur, aut quia senectute iter eius conlapsum est, aut quia calculus vel concretum aliquid ex sanguine intus se opposuit; at mediocris quoque inflammatio saepe eam reddi naturaliter prohibet: idque non in viris tantummodo sed in feminis quoque interdum necessarium est". 
zmach tężcowych ${ }^{111}$, o kłopotach trawiennych i ruchowych oraz ich zależności od pór roku, zwłaszcza od zimy ${ }^{112}$, o konkretnych starczych defektach fizycznych, jak sucha i pomarszczona skóra ${ }^{113}$, pomarszczona rogówka w oczach ${ }^{114}$, osłabiony puls ${ }^{115}$, impotencja ${ }^{116}$, siwizna ${ }^{117}$, wypadanie zębów i włosów oraz $ł y s i n a^{118}$, czy drżenie członków ${ }^{119}$. Lekarze tego okresu mówią też już często i konkretnie o starczych defektach sfery psychicznej, uważanych za naturalną konsekwencję starczego wyziębienia i wysuszenia, jak upór ${ }^{120}$, utrata pamięci $^{121}$, otępienie zmysłów ${ }^{122}$, czy starcza demencja ${ }^{123}$. Oni też próbowali wskazać przyczyny tych starczych ułomności oraz odpowiednią ich terapię, głównie o charakterze ocieplającym i nawilżającym, przeciwstawną wyziębianiu i wysuszeniu starego organizmu, zawierającą w sobie zarówno odpowiednio kaloryczną dietę alimentarną, jak i odpowiednie ćwiczenia fizyczne

${ }^{111}$ Areteusz (De curatione diuturnorum morborum I 5, 3-4) zauważa, że u osób starszych występują częste i różnego rodzaju niebezpieczne konwulsje i spazmy tężcowe: „Starzy częściej niż inni na nie cierpią i umieraja, a powodem tego jest wyziębienie i suchość starości oraz natura śmierci. Jeśliby bowiem zimno połączyło się ze suchością, owe konwulsje byłyby nieszkodliwe i mniej niebezpieczne".

112 Por. Celsus, De medicina II 1, 17, ed. Spencer I 94: „Quod ad aetates vero pertinet, pueri proximique his vere optime valent, et aestate prima tutissimi sunt, senes aestate et autumni prima parte, iuvenes hieme quique inter iuventam senectutemque sunt. Inimicitior senibus hiems, aestas adulescentibus est"; tenże, II 7, 9, Spencer I 120; Aretaeus, De curatione diuturnorum morborum II 5; Paulus Aegineta, Epitomae medicae III 13, 1; Alexander Trallianus, Therapeutica II 2.

${ }^{113}$ Por. Galenus, De sanitate tuenda I 2, Kühn VI 4; XI 508; Plinius, Naturalis historia IX 109; Oribasius, Collectiones medicae 54.

${ }^{114}$ Por. Galenus, De usu partium 10, 5, Kühn III 783; Aetius, Iatricorum VII 49.

${ }^{115}$ Por. Marcellinus, De pulsibus 349 (ed. H. Schöne); Rufus Ephesius, Synopsis de pulsibus 4; Galenus, De pulsibus, Kühn VIII 453-492; Ps-Galenus, Definitiones medicae 221, Kühn XIX 409.

${ }^{116}$ Por. Galenus, De semine II 5, Kühn IV 578.

${ }^{117}$ Por. Medicina Plinii I 5, 5; Serenus Sammonicus, Liber medicinalis 43.

${ }_{118}$ Por. Celsus, De medicina VI 1, Spencer II 178: „caput quibusdam aetate nudetur, succurri nullo modo potest"; Theodorus Priscianus, Physica I 3, 7; Plinius, Historia naturalis VII 176; Aretaeus, De curatione diuturnorum morborum I 6, 4; Aetius, Iatricorum VIII 21, 14.

${ }^{119}$ Por. Galenus, De sanitate tuenda I 2, Kühn VI 4; Paulus Aegineta, Epitomae medicae III 21; Mazzini, La geriatria di epoca romana, s. 355.

${ }^{120}$ Por. Caelius Aurelianus, Chronicon III 8, 9.

${ }^{121}$ Por. Plinius, Historia naturalis XXV 9: mowa o Antoniuszu Kastorze, który mimo osiagnnięcia 100 lat życia, nie utracił pamięci ani wigoru fizycznego; Aetius, Iatricorum VI 23.

122 Por. Plinius, Historia naturalis VII 176; Galenus, In Hippocratis libros epidemiarum commentarii VI-XVIIB.

${ }^{123}$ Por. Aretaeus, De curatione diuturnorum morborum II 1, 6 i 3, 6; Galenus, Quod animi mores corporis temperamenta sequantur 5, Kühn IV 786-787: „Obłąkanie nie ma nic wspólnego z demencją ( $\lambda \eta \dot{\rho} \eta \varsigma$ ), plagą starości, która się charakteryzuje otępieniem zmysłów, spowolnieniem możliwości intelektualnych lub umysłu, będących konsekwencją wyziębienia [...]. Nie należy jej

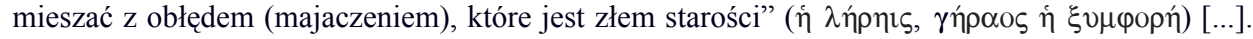
Dlaczego wielu z tych, którzy osiagnęli granice starości, bredzi, skoro wykazano, że okres starości był suchy. My twierdzimy, że przyczyną tego nie jest ich wysuszenie, ale ich wyziębienie, ponieważ zimno uszkadza wszystkie funkcje duszy"; Mazzini, La geriatria di epoca romana, s. 352-353. 
(masaże, spacery, gimnastykę), a niekiedy i kurację estetyczną i intelektualną ${ }^{124}$. Wszystkie te dane i pouczenia są, w porównaniu z okresem przedchrześcijańskim, już ściślej określone, często zdefiniowane i usystematyzowane, suponujące wcześniejsze badania anatomiczne poprzez sekcję ciała ludzkiego lub jego długą obserwację, a także pewne formy farmakologii; wszystko to stwarza fundamenty nowej dyscypliny medycznej - geriatrii, a także nowej specjalności terapeutycznej - geriatry ${ }^{125}$, które Innocenzo Mazzini nazywa „nowością epoki rzymskiej” („,novità di epoca romana”) ${ }^{126}$. Trzeba tu też dodać, że Galen, który, jak wspominaliśmy, rozpatrywał problem starości zarówno teoretycznie jak i praktycznie, oraz wywarł decydujący wpływ na poglądy późniejszych medyków, nie uważał jej za chorobę, choćby nawet zgodną z natura, jak wcześniej utrzymywał również wielce wpływowy Arystoteles ${ }^{127}$, ale twierdził, że jeśli jest ona fenomenem naturalnym, to nie może być w ogóle nazywana chorobą, a to, jak zauważa I. Mazzini, przynajmniej z dwóch racji: ponieważ choroba jest stanem pozanaturalnym (,,praeternaturale”), natomiast starość nie sprawia bólu ani nie przeszkadza różnym częściom ciała wypełniać swoich funkcji, jak to powoduje prawdziwa choroba ${ }^{128}$.

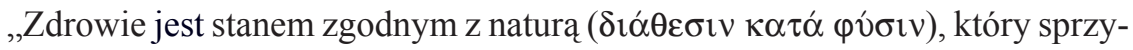
ja działaniu, choroba przeciwnie, jest stanem pozanaturalnym ( $\pi \alpha \rho \grave{\alpha} \varphi v ́ \sigma ı v)$, który jej szkodzi" ${ }^{29}$.

Na wszystkie wymienione wyżej słabości ludzi starych medycy okresu patrystycznego proponowali odpowiednią terapię, wyrażającą się zwłaszcza

${ }^{124}$ Por. Galenus, De sanitate tuenda V 3-5, Kühn VI 319-339; De simplicium medicamentorum temperamentis ac facultatibus I 8, Kühn XI 395; Oribasius, Synopsis ad Eustathium V 18; Aethius, Iatricorum II 91; Paulus Aegineta, Epitomae medicae I 23.

${ }^{125}$ Por. F. Kudlien, Medicina helenistica y helenistico-romana (300 a.C. -100 d.C.), w: Historia universal de la medicina, ed. P. Lain Entralgo, II, Barcelona 1972, 153-199; tenże, Der griechische Arzt im Zeitalter des Hellenismus. Seine Stellung in Staat und Gesellschaft, Wiesbaden 1979; B.E. Richardson, Old age among the ancient Greek, Baltimore 1955, 231-236; Mazzini, La geriatria di epoca romana, s. 344-345 i 351-355.

${ }^{126}$ Por. Mazzini, La geriatria di epoca romana, s. 344-345, 351-353.

${ }^{127}$ Por. Aristoteles, De generatione animalium V 4, 784b, tłum. P. Siwek, s. 229-230: „Toteż słusznie można by nazwać chorobę «starością nabytą», a starość «chorobą naturalną». W każdym razie niektóre choroby wywołują te same skutki, co starość"; Byl, La gérontologie dans le Corpus Hippocratique, s. 75.

${ }^{128}$ Por. Mazzini, La geriatria di epoca romana, s. 351.

${ }^{129}$ Galenus, De sanitate tuenda I 5, Kühn VI 20; tamże VI 2, Kühn VI 387-388: „U wszystkich, którzy osiaggnęli wiek największego wigoru, potem tracą swe siły, ci [starzy] jednak nie tracą zdrowia, chociaż jest ono gorsze niż wcześniej; mają je nie tylko na początku starości, ale także podczas niej,

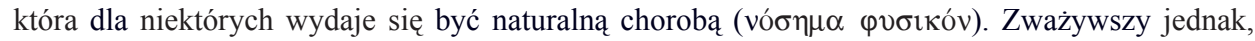
że nie są oni dręczeni przez jakieś specjalne bóle, ani nie stracili sił niezbędnych do pełnienia akcji witalnych, ani nie stali się całkowicie bezsilni, powinni się czuć zdrowi, oczywiście takim zdrowiem, jakie jest właściwe starości [...]. Pełne zdrowie bez uszczerbku zasadza się w tym, co dotyczy wypełniania wszystkich funkcji (życiowych), tymczasem zdrowie człowieka starego ma już pewne braki”. 
w dostosowanej diecie, głównie alimentarnej, odpowiednie ćwiczenia ruchowe, a także pewne ingerencje chirurgiczno-farmakologiczne, a nawet estetyczne; również i w tej dziedzinie najobszerniej i najkonkretniej wypowiadał się Galen. Zalecenia te są już w tym okresie bardziej usystematyzowane i uporządkowane, uwzględniające szerzej nie tylko fizjologię starzejącego się człowieka, ale i etiologię samego procesu starzenia się.

\section{TERAPIA LUDZI STARYCH}

Wielu lekarzy okresu patrystycznego proponowało różne sposoby opieki nad ludźmi starymi oraz konkretne środki niwelujące defekty i słabości ich wieku starczego, ale chyba najszerzej uczynił to, jak wspominaliśmy, żyjący w II wieku przyboczny lekarz cesarski Galen z Pergamonu, co opisał przede wszystkim w takich swoich dziełach, jak: De sanitate tuenda, De mercore, De simplicium medicamentorum temperamentis ac facultatibus oraz De naturalibus facultatibus.

1. Propozycja Galena. Ze wszystkich medycznych propozycji terapii ludzi starych w okresie patrystycznym najpełniejszą i najwszechstronniejszą wydaje się być Galena. I on, jak znakomita większość medyków tego okresu, wiązał starość $\mathrm{z}$ utratą wrodzonego ciepła i wysuszeniem organizmu ${ }^{130}$, i podawał wskazówki, jak temu nieuchronnemu zjawisku zapobiegać, spowalniać je lub niwelować jego skutki. W programie jego terapii oprócz diety alimentarnej, dotyczącej różnych pokarmów i napojów, figurują również kąpiele, masaże, należyty sen, ćwiczenia i spacery, a nawet umiarkowane uprawianie seksu, by na końcu przypomnieć wzorce praktykujących te zalecenia.

a. Dieta pokarmowa. Galen osobom starszym niektóre pokarmy zaleca, inne odradza, podobnie jak i używanie napojów, zwłaszcza wina, proponując zawsze $\mathrm{w}$ tym wszystkim umiar i indywidualne ich dostosowanie do stanu zdrowia każdego, a nawet pory roku:

„Stan zdrowia ciała tych, którzy są w pełni sił, nie zmienia się nawet z powodu jakiejś mocnej przyczyny, u ludzi starych jednak nawet najmniejsza przyczyna jest okazją do zmiany. Dotyczy to zarówno jakości, jak i ilości pokarmu, nawet jeśliby przekroczyli tylko niewielkie jego granice, mogą doznać niemałych trudności [...] dlatego też jest rzeczą bezpieczniejsza, ludziom starym, którzy są słabi, podawać pokarm w małej ilości i trzy razy dziennie"131.

${ }^{130}$ Por. A. Bednarczyk, System filozoficzno-lekarski Galena (130-200): pojęcie ciepła przyrodzonego i pneumy życiowej, „Analecta” 2 (1993) z. 1, 53-111, lub w tegoż: Galen. Główne kategorie systemu filozoficzno-lekarskiego, Warszawa 1995, 115-199; J. Scarborough, Roman medicine to Galen, ANRW II 37.1, Berlin - New York 1996, 1-48.

${ }^{131}$ Galenus, De sanitate tuenda V 4, Kühn VI 331-332; J. Moszyński: Galenus, De victu attenuante, „Archiwum Historii Medycyny” 45 (1982) 61-75; M. Amerise, Girolamo e la senectus, 
„Ludzie starzy nie powinni jeść w nadmiarze pokarmów mącznych, serów, jajek na twardo, potraw z muszli, cebuli, soczewicy i mięsa wieprzowego, powinni uważać na potrawy z węgorzy, ostryg i tych zwierząt, których mięso jest trudno strawne; $z$ tej samej przyczyny szkodliwe są potrawy ze zwierząt zamkniętych w skorupach, chrząstkowatych, tuńczyków i wielorybów, a spośród mięs - mięso z jelenia, kozy i wołu [...]. Nie jest natomiast szkodliwe dla ludzi starych mięso z jagnięcia czy ptaków, które żyją daleko od bagien, rzek i stawów. Wszystkie mięsa wymagające solenia są lepsze od zimnych. W każdym wypadku należy unikać przede wszystkim tych pokarmów, które wywołują niestrawność [...]. Jeśli, chodzi o chleb, to ludzie starsi winni unikać takich, które nie są solone, wypieków drożdżowych, nadmiernie wypieczonych i w ogóle mącznych oraz potraw z nimi związanych. [...] Jeśli chodzi o ciastka mączne z masłem, to nie należy dodawać do nich za wiele miodu, bo nie ma od nich nic szkodliwszego dla ludzi, a tym bardziej ludzi starych"132.

$\mathrm{Z}$ napojów Galen zalecał ludziom starym picie m.in. wina, jako lekarstwa na ich wysuszenie i wyziębienie. To co nas przy tym uderza, to wielka ilość różnych proponowanych przez niego win, które należy dobierać do wieku oraz okolicy, a nawet pory roku, uwzględniając również ich gęstość i kolor:

„O ile wino jest całkowicie zakazane dzieciom, o tyle jest ono wielce pożyteczne dla ludzi starych; w szczególności wina z natury rozgrzewające, jak u Greków Ariusio i Lesbico oraz to nazywane Misio, ale nie Misia, które jest z Istrii. Z win zaś italskich zalecane jest Falerno i Sorrentino ${ }^{133}[\ldots]$... Ludzie starsi powinni pić wina umiarkowanie stare. W każdej zaś okolicy, każdy winien dobierać wino dla siebie najodpowiedniejsze, bacząc oczywiście przy jego dobieraniu na wiek człowieka starego, które jest najlżejsze, ze względu na gęstość i kolor [...]. Najcieplejsze ze względu na kolor jest żółte, a mniej ciepłe - białe. Pierwszą wielką korzyścią płynącą z wina dla ludzi starych jest to, że rozgrzewa wszystkie ich części. Wśród win, te które są białe i żółte oraz które są gęste, one rodzą krew i dokarmiają ciało. Dlatego też te wina są pożyteczne dla starych w czasie, kiedy nie mają wilgotności w żyłach i potrzebują większego dokarmienia [...]. W tym wieku zachodzi też wielka potrzeba win moczopędnych"134.

b. Dieta życiowa. Obok diety alimentarnej Galen proponuje ludziom starym także inne zajęcia terapeutyczne związane z ruchem, mające na celu oży-

Roma 2008, 91-100 (Le norme dietetiche e igieniche); V.E. Grimm, From feasting to fasting, the evolution of a sin. Attitudes to food in Late Antiquity, London - New York 1996.

${ }^{132}$ Galenus, De sanitate tuenda V 6, Kühn VI 339-340; podobnie por. tenże, De naturalibus facultatibus II 8, Kühn II 123; De simplicium medicamentorum temperamentis ac facultatibus I 8 , Kühn XI 395; Mazzini, La geriatria di epoca romana, s. 357.

${ }^{133}$ Por. także Galenus, De simplicium medicamentorum temperamentis I 8, Kühn XI 395.

${ }^{134}$ Galenus, De sanitate tuenda V 5, Kühn VI 334-339; por. Mazzini, La geriatria di epoca romana, s. 358; W. Turek, I fondamenti biblici e classici dei consigli di Clemente Alessandrino sull'uso del vino. Alcune osservazioni su „Pedagogo” II 2, w: Cultura e promozione umana, s. 279-290. 
wienie i wzmocnienie ich organizmu, a należą do nich gimnastyka, kapiele, masaże i spacery, uprawianie seksu, a także podglądanie i naśladowanie sposobu życia długowiecznych starców. Jeśli chodzi o kąpiele, to:

„Ponieważ starość jest zimna i sucha, jej leczenie dokonuje się przez to wszystko, co nawilża i rozgrzewa; takimi zaś są gorące kąpiele w miłej wodzie" ${ }^{135}$.

Ludziom starym zaleca także pewne ćwiczenia fizyczne, ale tylko niektóre, jak spacery, masaże, czy inne ruchy, a wszystko to z umiarem i stopniowaniem oraz dostosowaniem do stanu zdrowia poszczególnych osób:

„Ludzie starzy, podobnie jak i młodzi, potrzebują ćwiczeń swego ciała, bo inaczej ich wrodzone ciepło narażone jest na spadek [...]. Ich ciepło winno być odnawiane, a jest ono tracone przez ruchy zbyt gwałtowne [...]. Masaż stymulując ich siły witalne i rozgrzewając ich w sposób umiarkowany, ułatwia im trawienie, a przyjmowany pokarm lepiej jest przyswajany [...] i dlatego dla ludzi starych nie ma nic lepszego niż poranna gimnastyka; nacieranie olejem, a bezpośrednio potem spacer i ruch bez zmęczenia, mając zawsze na względzie siły starego człowieka [...]. Rodzaje ćwiczeń dla ludzi starych, które z nich są pożyteczne a które mogą szkodzić, należy dostosowywać do dyspozycji ich ciała i do ułomności, które im dolegają [...]. Takich zaś ćwiczeń, które wykonują profesjonaliści, ludzie starzy nie mogą nawet próbować wykonywać, jak gry na flecie, trąbie, czy cytrze; nie mogą również wykonywać ćwiczeń praktykowanych podczas zawodów w palestrze, jeśli nie są do nich przyzwyczajeni”'136.

Galen nie pominął też tak ważnej sfery dla człowieka starożytnego, jak uprawianie seksu przez ludzi w podeszłym wieku, odradzając jego praktykowanie starcom o suchym temperamencie, bo wyziębia on i wysusza ich organizmy:

„Aktywność seksualna jest szkodliwa dla tych wszystkich, którzy mają suchy temperament, a szczególnie dla tych, którzy obok tego, że są susi, są także zimni”'137.

Pamiętając zaś o starej wychowawczej zasadzie, że „verba docent, exempla trahunt”, Galen obok konkretnych zaleceń słownych, wskazywał również na pewne przykłady długo żyjących ludzi, których dietę i sposób życia warto naśladować. Takimi ulubionymi postaciami byli dla niego lekarz Antioch i gramatyk Telefor, który mimo osiagnnięcia 80 lat życia, nadal byli bardzo sprawni i aktywni, przez co ich sposób życia może być godny naśladowania; oto przedstawiona przez niego sylwetka Antiocha medyka:

„Najbezpieczniej jest podawać staremu słabemu człowiekowi po niewielkiej ilości pokarmu trzy razy dziennie; tak też żywił się lekarz Antioch osiagnąwszy 80. rok życia. Każdego dnia chodził na rynek, na miejsce, gdzie się zbierali oby-

\footnotetext{
${ }^{135}$ Tamże V 3, Kühn VI 319.

${ }_{136}$ Tamże, Kühn VI 319-326; Mazzini, La geriatria in epoca romana, s. 356-357.

${ }^{137}$ Tamże VI 4, Kühn VI 402.
} 
watele; przemierzał też wtedy długie ulice, aby odwiedzać chorych. Aby dojść ze swego domu na rynek, przemierzał prawie trzy stadia. Tak chodząc zawsze pieszo odwiedzał starych chorych, a jeśli musiał iść dalej, pozwalał się przenosić w lektyce lub na wozie. W domu miał pokój, który podczas zimy był ogrzewany kominkiem, a podczas lata nawet bez palenia ogniska miał odpowiednią temperaturę. $\mathrm{W}$ tym to przede wszystkim pokoju w zimie i w lecie masowano mu ciało. Na rynku około godziny trzeciej, lub nawet później około czwartej, jadał chleb z attyckim miodem, lepiej upieczony, rzadko niedopieczony. Potem spędzał czas częściowo na rozmowach, a częściowo na czytaniu aż do godziny siódmej; później masowano go w łaźniach publicznych, gdzie też wykonywał ćwiczenia odpowiednie dla ludzi starych [...]. Potem się kapał i jadł umiarkowanie: najpierw spożywał takie pokarmy, które ułatwiały opróżnienie, potem jadł więcej ryb spod skał podwodnych lub pochodzących z głębokiego morza. Później przy kolacji powstrzymywał się od jedzenia nowych ryb, nie spożywał pokarmów mocno nasączonych i trudnostrawnych, a brał albo kaszę orkiszową z miodowym winem, albo ugotowanego kurczaka z chudym rosołem. Antioch troszcząc się w ten sposób o siebie posiadał do ostatniego dnia swego życia pełną wrażliwość zmysłów oraz wszystkie członki sprawne bez zastrzeżeń" ${ }^{138}$.

Oto idealny, godny naśladowania, program dnia starego wolnego człowieka, proponowany przez Galena. Podobny godny naśladowania przykład wzorowego starca ukazał Galen na osobie gramatyka Telefosa ${ }^{139}$. Program diety dla osób starszych, zaprezentowany przez Galena w V księdze traktatu De sanitate tuenda, był potem mniej lub więcej dokładnie powtarzany przez późniejszych medyków - Oribazjusza, Aecjusza, czy Pawła z Eginy, choć ten ostatni nie wspomina o kąpieli, inni zaś redukują drastycznie ilość spożywanych pokarmów i napojów ${ }^{140}$.

2. Propozycja Celsusa. O wiele skromniejszy program diety dla starego człowieka zaproponował wcześniej żyjący za cesarza Tyberiusza w Rzymie encyklopedysta Aulus Korneliusz Celsus, autor obszernej w VIII księgach encyklopedii medycznej pt. De medicina, której pierwszą księgę poświęcił właśnie diecie, a drugą pospolitym środkom dietetycznym, w tym również osobom starszym ${ }^{141}$. Nowością jego programu terapeutycznego dla starców, w porównaniu do Hipokratesa, jest zalecanie obok innych środków, częstej

${ }^{138}$ Tamże V 4, Kühn VI 332, Mazzini, La geriatria in epoca romana, s. 358-359.

${ }^{139}$ Por. Galenus, De sanitate tuenda V 5, Kühn VI 333-334.

${ }^{140}$ Por. I. Mazzini, Alimentazione e salute secondo i medici del mondo antico: teoria e realtà, w: Homo edens: regimi, miti e pratiche dell'alimentazione nella civiltà del Mediterraneo. Atti del convegno, ed. O. Longo - P. Scarpi, Verona 1989, 257-264; Mazzini, La geriatria in epoca romana, s. 360.

${ }^{141}$ O Celsusie por. M. Cytowska - H. Szelest, Literatura rzymska. Okres cesarstwa, Warszawa 1992, 63; S. Contino, Aulo Cornelio Celso. Vita e opera, Palermo 1980; T.H. Howel, Celsus on old age, „Age and Ageing” 15 (1986) 378-579; Mazzini, La geriatria di epoca romana, s. 359; Ph. Mudry, L'orientation du „De medicina” de Celse, ANRW II 37.1, Berlin - New York 1996, 800-818; tenże, Le „De medicina” de Celse. Rapport bibliographique, tamże, s. 787-799. 
kąpieli w łaźniach (podobnie czynił później Galen), której poświęca wiele miejsca. Przy stosowaniu tych środków, w tym również przy diecie alimentarnej, zalecał zawsze umiar, stopniowanie, uwzględnianie wieku, pór roku, stanu zdrowia i temperamentu starca; zalecał też nierzadko środki chirurgiczne, których stosowanie dokładnie opisywał:

„Jeśli chodzi o wiek, to najłatwiej znoszą post osoby średniego wieku, mniej młodzi, a najmniej dzieci i wyczerpani starcy. Im ktoś gorzej znosi post, tym częściej powinien jeść, a najbardziej ten, kto jeszcze rośnie. Gorąca kapiel odpowiednia jest dla dzieci i ludzi starych. Małym dzieciom należy podawać wino bardziej rozcieńczone, osobom zaś starszym raczej czyste, w żadnym zaś z tych wieków nie należy podawać tego, co wywołuje wzdęcia [...]. Którzy w młodości mieli rozwolnienia, w starości cierpią często zatwardzenia, którzy zaś w młodości mieli zatwardzenia, często w starości cierpią rozwolnienia. Lepiej jest, żeby opróżnienia u młodych były bardziej rozwolnione, a w starości bardziej zatwardzone [...]. Należy także uwzględniać pory roku"142.

3. Terapia chirurgiczno-farmaceutyczna. Starożytność znała też pewne działania chirurgiczne i farmakologiczne, mające na celu usuwanie lub przynajmniej zmniejszanie defektów i słabości wieku starczego. Znane są śmiałe i odważne praktyki medyków aleksandryjskich, jak usuwanie kamieni z pęcherza moczowego, usuwanie katarakty, operacje przepukliny, czy usuwanie różnych torbieli z wnętrza brzucha, a nawet pewne operacje laryngologiczne ${ }^{143}$. Działania te w okresie patrystycznym jeszcze poszerzono i wyspecjalizowano, czego echa spotykamy w źródłach tego czasu.

${ }^{142}$ Celsus, De medicina I 3, 32-36, ed. W.G. Spencer, I, Cambridge Mass. - London 1960, 64-66: „Quod ad aetates vero pertinet, inediam facillime sustinent mediae aetates, minus iuvenes, minime pueri et senectute confecti. Quo minus fert facile quisque, eo saepius debet cibum adsumere, maximeque eo eget, qui increscit. Calida lavatio et pueris et senibus apta est. Vinum dilutius pueris, senibus meracius: neutri aetati, quae inflationes movent. Iuvenum minus quae adsumarit et quomodo curentur, interest. Quibus iuvenibus fluxit alvus, plerumque in senectute contrahitur: quibus in adulescentia fuit adstricta, saepe in senectute solvitur. Melior est autem in iuvene fusior, in sene adstrictior. Tempus quoque anni considerare oportet. Hieme plus esse convenit, minus sed meracius bibere; multo pane uti, carne potius elixa, modice holeribus; semel die cibum capere, nisi si nimis venter adstrictus est. Si prandet aliquis, utilius est exiguum aliquid, et ipsum siccum sine carne, sine potione sumere. Eo tempore anni calidis omnibus potius utendum est vel calorem moventibus. Venus tum non aeque perniciosa est. At vere paulum cibo demendum, adiciendum potioni, sed dilutius tamen bibendum est; magis carne utendum, magis holeribus; transeundum paulatim ad assa ab elixis. Venus eo tempore anni tutissima est. Aestate vero et potione et cibo saepius corpus eget; ideo prandere quoque commodum est. Ei tempori aptissima sunt et caro et holus, potio quam dilutissima, ut et sitim tollat nec corpus incendat; frigida lavatio, caro assa, frigidi cibi vel qui refrigerent".

${ }^{143}$ Por. M. Michler, Das Spezialisierungsproblem und die antike Chirurgie, Stuttgart - Wien 1969; D. Rüster, Alte Chirurgie. Legende und Wirklichkeit, Köln 1986, 76-79; I. Mazzini, La chirurgia celsiana nella storia della chirurgia greco-romana, w: Celse, ed. Ph. Mudry - G. Sabbah, Saint Etienne 1994, 155-166. 
a. Działania chirurgiczne. Także w geriatrii podejmowane były w tym czasie często pewne inicjatywy chirurgiczne, które miały na celu usuwanie dolegliwych, rażących czy oszpecających defektów starości. Znane było m.in. skomplikowane, choć przez Celsusa w pełnej starości odradzane, usuwanie katarakty z oczu, której operację, jej przebieg i późniejszą terapię, dokładnie sam opisuje ${ }^{144}$, znane były również, choć przez tego autora także odradzane w podeszłym wieku, operacje kształtujące obwisłe wargi ${ }^{145}$, usuwanie przepukliny pępkowej ${ }^{146}$, popularne w starożytności upuszczanie krwi, które Celsus dopuszczał tylko u ludzi starszych fizycznie mocnych ${ }^{147}$, czy też usuwanie kamieni z pęcherza moczowego ${ }^{148}$. Tenże Celsus zaleca również chirurgiczne usuwanie różnego rodzaju zwisających czy sterczących narośli starczych, jak o tym świadczy następująca jego wypowiedź:

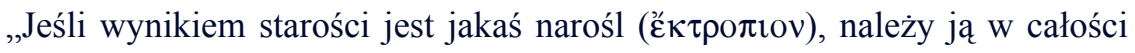
usunać cienkim żelazem, zarówno to co zwisa lub wystaje na zewnątrz, a potem miejsce to posmarować miodem; począwszy zaś od czwartego dnia nagrzewać ciepłą parą wodną i smarować maściami zabliźniającymi”149.

${ }^{144}$ Por. Celsus, De medicina VII 7, 14BC, Spencer III 348-350: „Neque idonea curationi senilis aetas est, quae sine eo vitio tamen aciem hebetem habet: at ne puerilis quidem, sed inter haec media. Oculus quoque curationi neque exiguus neque concavus satis oportunus est. Atque ipsius suffusionis quaedam maturitas est: expectandum igitur est, donec iam non fluere sed duritie quadam concrevisse videatur. Ante curationem autem modico uti cibo, bibere aquam triduo debet, pridie ab omnibus abstinere. Post haec in advorso collocandus est, loco lucido, lumine adverso, sic ut contra medicus paulo altius; a posteriore parte caput eius, qui curabitur, minister contineat, ut inmobile id praestet: nam levi motu eripi acies in perpetuum potest. Quin etiam ipse oculus, qui curabitur, inmobilior faciendus est, super alterum lana inposita [deligata]: curari vero sinister oculus dextra manu, dexter sinistra debet"; L. Limmer - G.K. Krieglstein, Augenheilkunde im Rom der frühen Kaiserzeit: A.C. Celsus, De medicina, „Revue d'Histoire des Sciences et de leurs Applications” 47 (1994) 300-302.

${ }^{145}$ Por. tamże VII 9, 2, Spencer III 362.

${ }^{146}$ Por. tamże VII 14, 7, Spencer III 380-382: „Post haec umbilicum adtrahere, et qua nota atramenti est, lino vehementer adstringere; deinde partem superiorem aut medicamentis aut ferro adurere, donec emoriatur, atque ut cetera usta ulcus nutrire. Idque non solum ubi intestinum vel omentum vel utrumque est, sed etiam ubi umor est, optime proficit. Sed ante quaedam visenda sunt, ne quod ex vinculo periculum sit. Nam curationi neque infans neque aut robustus annis aut senex aptus est, sed [...] a septimo fere anno ad quartum decimum".

${ }^{147}$ Por. tamże II 10, 1 i 3, Spencer I 154-156; Galenus, In Hippocratis de victu acutorum morborum commentaria 17; Aethius, Iatricorum V 71; Paulus, Epitomae medicae II 17; V 71.

${ }^{148}$ Por. Paulus, Epitomae medicae VI 60.

${ }^{149}$ Celsus, De medicina VII 7, 10, Spencer III 342-344: „Ut superioris autem palpebrae vitium est, quo parum descendit ideoque oculum non contegit, sic inferioris, quo parum susum attollitur, sed pendet et hiat, neque potest cum superiore committi. Atque id quoque evenit interdum ex simili vitio curationis, interdum etiam senectute: ectropion Graeci nominant. Si ex mala curatione est, cadem ratio medicinae est, quae supra posita est; plagae tantum cornua ad maxillas, non ad oculum convertenda sunt: si ex senectute est, tenui ferramento id totum extrinsecus adurendum est, deinde mello inunguendum: a quarto die vapore aquae calidae fovendum, inunguendumque medicamntis ad cicatricem perducentibus"; Mazzini, La geriatria in epoca romana, s. 360. 
b. Kuracja farmokologiczna. Dolegliwości ludzi starych starano się od zarania starożytności leczyć także środkami farmakologicznymi, specjalnymi lekarstwami, głównie ziołowymi lub naturalnymi, choć biorąc pod uwage ich osłabienie i stosowaną przez nich starczą dietę oraz sposób życia ${ }^{150}$, nie było ich jeszcze za wiele, jakkolwiek i te, w porównaniu z poprzednią epoką, stanowiły już niemało nowości. Tak np. Celsus wspomina o pewnych plastrach z gotowanej mieszaniny bieli cynkowej, cielęcego łoju, wosku i oleju, szczególnie skutecznych na rany ludzi starych ${ }^{151}$, Aecjusz zaleca środki po-

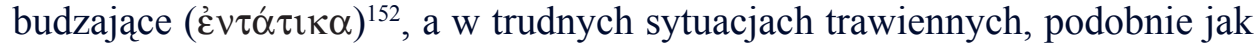
i Galen, środki rozwalniające i przeczyszczające ${ }^{153}$, przy znużeniu zaś środki pokrzepiające i usuwające zmęczenie (ó $\alpha$ Ko $\pi \alpha)^{154}$.

4. Terapia estetyczna. Starożytni ludzie podeszłego wieku stosowali również nierzadko pewne zabiegi medyczne, które miały usuwać lub przynajmniej zmniejszać niektóre defekty starości ze względów estetycznych; do tego rodzaju zewnętrznych defektów, które oszpecały ich ciało, należały m.in. siwe włosy, łysina, bezzębność, osłabienie wzorku i słuchu, różnego rodzaju narosty oraz zmarszczki. Chęć ich usunięcia, lub przynajmniej ukrycia, świadczą z jednej strony o pragnieniu uczestnictwa tych osób jeszcze w publicznym życiu kulturalno-społecznym, w którym chciały się one jak najokazalej prezentować, z drugiej zaś stanowią pewną nowość w sztuce medycznej. Tego rodzaju terapię estetyczną poświadczają m.in. dwa świadectwa z IV wieku - Liber medicinalis Serenusa Samonika oraz przypisywana mylnie Pliniuszowi Starszemu Medicina Plinii. Oto ich brzmienie, dotyczące głównie ukrycia siwizny:

„Kto się wstydzi swych lat i jest niezadowolony ze swej czcigodnej starości, pragnie ukryć swe siwe włosy, upodabniając je do czarnych oszukańczą farbą; może do tego użyć albo startego cypru w occie, albo liści lentyszka albo gorzkich owoców czarnego bzu; także dżdżownice z ziemi, zmiażdżone i zmieszane z oliwą czynią włosy młodymi i przywracają im dawny blask"155.

${ }^{150}$ Por. Galenus, De sanitate tuenda V 9; Oribasius, Synopsis ad Eustathium V 18; Aetius, Iatricorum III 23; Paulus, Epitomae medicinae I 23.

${ }^{151}$ Por. Celsus, De medicina V 19, 23, Spencer II 42: „Sunt etiam alba lenia (leuca Graeci vocant) fere non gravibus vulneribus accommodata, praecipueque senilibus. Quale est quod habet: cerussae P. * XXXII; sebi vitulini curati et cerae, singulorum P. * XLVIII; olei heminas tres; ex quibus ea cerussa coquitur; F. Martinez Saura, La farmacoterapia en Celso y Escribonio Largo, „Espacio, tiempo y forma. Madrid” 8 (1995) 439-474 (starożytna lista leków pochodzenia roślinnego, mineralnego i zwierzęcego); taż, La terapeutica extrafarmacologica en A. Cornelio Celso: antecedentes, „Hispania Antiqua” 20 (1996) 297-324 (zapoczątkowana przez Celsusa balneoterapia, kauteryzacja, psychoterapia, farmakologia, i różnego rodzaju chirurgiczne operacje).

${ }^{152}$ Por. Aetius, Iatricorum XI 35.

${ }^{153}$ Por. tamże IV 30; Galenus, De sanitate tuenda V 9.

${ }^{154}$ Por. Galenus, De compositione medicamentorum per genera VII 16, ed. Kühn XIII 1048.

${ }^{155}$ Serenus Sammonicus, Liber medicinalis 43-59. 
„Tym, którzy się wstydzą swej starości doradzam: jeśli chcą farbować swoje siwe włosy, mając nadzieję, że w ten sposób odejmą sobie lat, niech używają popiołu z robaków ziemi w oleju, którym niech namaszczają sobie głowę"156.

Wiele innych analogicznych recept na usunięcie siwizny dostarczają nam również inni medycy tego okresu, jak Galen z Pergamonu ${ }^{157}$, Teodor Pryscjan ${ }^{158}$, Marcellus Empiryk ${ }^{159}$, czy Aleksander z Tralles ${ }^{160}$. Podobnych wyjaśnień o łysinie, że jest ona nieodwracalną cechą starości, dostarczają nam Celsus ${ }^{161}$ i Pryscjan ${ }^{162}$. Także na zmarszczki, których usunięciem lub ukryciem zainteresowane były przede wszystkim kobiety, pewne medykamenty proponował już nie tylko Hipokrates ${ }^{163}$ a za czasów Cesarstwa m.in. Orybazjusz ${ }^{164}$.

Choć medycy starożytni świadomi byli, że starości nie można uniknąć ani z niej się wyleczyć, to głównie na prośby podeszłych wiekiem pacjentów starali się ją przez podawane leki lub nawet chirurgiczne zabiegi nieco opóźnić lub jej dolegliwości osłabić, podobnie jak i związane z nią choroby, jak starcze osłabienie wzroku (caligo oculorum), na które próbowali znaleźć lekarstwo ${ }^{165}$, lub majaczenia $(\lambda \hat{n} \rho \varepsilon \imath \varsigma)^{166}$, czy marazm (depresja, zgorzknienie); na zajmowanie się nimi wpływały również coraz mocniejsze chrześcijaństwo i względy humanitarne:

„Jak ze starości nie można nikogo wyleczyć, tak i z głębokiego marazmu, powinno się jednak świadczyć humanitarną pomoc i nie zostawiać nikogo bez wsparcia"167.

${ }^{156}$ Medicina Plinii I 5, 5; zob. Mazzini, La geriatria di epoca romana, s. 361.

${ }^{157}$ Por. Galenus, De compositione medicamentorum secundum locos I 3, Kühn XII 443.

${ }^{158}$ Por. Theodorus Priscianus, Physica I 2.

${ }^{159}$ Por. Marcellus Empiricus, De medicamentis VII 1-16.

${ }^{160}$ Por. Alexander Trallianus, Therapeutica I 3.

${ }^{161}$ Por. Celsus, De medicina VI 1, Spencer II 178: „In hoc igitur capillis fluentibus maxime quidem saepe radendo succurritur. Adicit autem vim quandam ad continendum ladanum cum oleo mixtum. Nunc de iis capillis loquor, qui post morbum fere fluunt: nam quominus caput quibusdam aetate nudetur, succurri nullo modo potest".

${ }^{162}$ Por. Theodorus Priscianus, Physica I 3, 1.

${ }^{163}$ Por. Hippocrates, De mulierum affectibus II 188, ed. Littré VIII 369.

${ }^{164}$ Por. Oribasius, Synopsis ad Eustathium V 20.

${ }^{165}$ Por. Celsus, De medicina VI 6, 32-34, Spencer II 220: „Caligare vero oculi nonnumquam ex lippitudine, nonnumquam etiam sine hac propter senectutem inbecillitatemve aliam consuerunt. $\mathrm{Si}$ ex reliquis lippitudinis id vitium est, adiuvat collyrium, quod Asclepios nominatur, adiuvat id, quod ex croci magmate fit. Proprie etiam ad id componitur, quod dia crocu vocant. Habet piperis P. * I; croci Cilici, papaveris lacrimae, cerussae, singulorum P. * II psorici, cummis, singulorum P. * IIII. At si ex senectute aliave inbecillitate id est, recte inungui potest et melle quam optumo et cypro et oleo vetere. Commodissimum tamen est balsami partem unam et olei veteris aut cypri partes duas, mellis quam acerrimi partes tres miscere".

${ }^{166}$ Por. Aretaeus, De curatione diuturnorum morborum III 6, 2.

${ }^{167}$ Por. Alexander Trallianus, De febribus, ed. T. Puschmann (Alexander von Tralles, Bd. I, Wien 1878, ristamp. Amsterdam 1963), s. 369; zob. Mazzini, La geriatria di epoca romana, s. 362. 
Na zakończenie powyższych uwag na temat starożytnej troski medycznej o ludzi starych, zwłaszcza w okresie patrystycznym, wypada postawić pytanie, jak do tego problemu odnosili się chrześcijanie? Czy chrześcijańscy medycy, powodowani choćby przykazaniem miłości bliźniego, zajmowali się specjalnie ludźmi starymi? Czy zakładali dla nich, zwłaszcza dla ubogich i chorych, jakieś stałe domy starców z zapewniona, choćby ogólną, opieką medyczną? Otóż świadectwa wczesnochrześcijańskie na ten temat są bardzo skape, a jeśli jakieś są, to pochodzą z późniejszego okresu. Żadne z nich nie poświadcza wprost teoretycznej lub praktycznej działalności lekarza wczesnochrześcijańskiego, choć zapewne tacy byli, jak na przykład męczennicy Kosma i Damian ${ }^{168}$, a jeśli Ojcowie Kościoła przypadkowo o tym wspominają lub posługują się terminologią medyczną (Atenagoras, Tertulian, Klemens Aleksandryjski, Orygenes, Cyprian z Kartaginy, Laktancjusz, Euzebiusz z Cezarei, Nemezjusz z Emezy, Grzegorz z Nazjanzu, Bazyli z Cezarei, Grzegorz z Nyssy, Ambroży z Mediolanu, Prudencjusz, Hilary z Poitiers, Hieronim, Augustyn) ${ }^{169}$, to najczęściej mówią o Chrystusie jako Lekarzu ${ }^{170}$; powodem tego było być może i to, że zawód ten nie cieszył się w starożytności dobrą opinią, a w oczach chrześcijan kojarzył się nierzadko z religią pogańską (Asklepios, asklepiejony) i magią ${ }^{171}$. Co do diety, sposobów pielęgnowania zdrowia i leczenia codziennych dolegliwości, w tym również wynikających ze starości, przestrzegali zapewne tradycyjnych zaleceń hipokratyków i późniejszych medyków (głównie Galena), o ile nie były one sprzeczne z moralnością chrześcijańską ${ }^{172}$. Jeżeli zaś chodzi o instytucje domów starców, to podobnie jak szpitale będące pomysłem

${ }^{168}$ Por. E. Rupprecht, Cosmae et Damiani sanctorum medicorum vita et miracula, Berlin 1935; F. Caraffa - M.L. Casanova, Cosma e Damiano, BS IV 223-237.

169 Por. Mazzini, La letteratura cristiana antica e la medicina, s. 353-372, spec. 355 i 369 372; G.B. Ferngren - D.W. Amundsen, Medicine and Christianity in Roman Empire, ANRW 37. 3, Berlin - New York 1996, 2957-2980; V. Dawe, The attitude of Ancient Church toward sickness and healing, Boston 1955; M. Perrin, Un exemple de l'utilisation de la médecine chez les penseurs chrétiens: Tertullien et l'embryologie, w: Médecine antique, ed. P. Demont, Amiens 1991, 91-117; zob. wyżej n. 77; Heyne T., Were second-century Christians 'preoccupied'with physical healing and the Asclepian cult?, StPatr 44 (2010) 63-70.

${ }^{170}$ Por. np. V. Lombino, Medico Cristo, NDPAC II 3168-3181; G. Dumeige, Le Christ médecin dans la littérature chrétienne des premiers siècles, RivAC 48 (1972) 115-141.

${ }^{171}$ Por. L. Edelstein, Greek Medicine in its relation to religion and magie, „Bulletin of the Institute of the History of Medicine" 5 (1937) z. 3, 201-246; S. Felici, Medicina religiosa, medicina magica, medicina scientifica nella civiltà classica Greca e Latina, w: Cultura e promozione humana, s. 75-94; G. Lanata, Medicina magica e religione popolare in Grecia fino all'età di Pericle, Roma 1967; G.G. Porro, Asclepio. Saggio mitologico sulla medicina religiosa dei Greci, Milano 1911.

172 Por. M. Pujiula, Körper und christliche Lebensweise. Clemens von Alexandrien und sein „Paidagogos”, Berlin - New York 2008, spec. 168-315 (m.in. Diätetik, Ernährung, Bad und Körperpflege, Kosmetik, Haarpflege, Gefahr der Verweiblichung, Balnea mixta); H. Schadewaldt, Die Apologie der Heilkunst bei den Kirchenväter, w: „Veröffentlichungen der Internationalen Gesellschaft für Geschichte der Pharmazie” 26 (1965) 115-130. 
i dziełem chrześcijan ${ }^{173,}$ pojawiły się później; poświadczają je źródła dopiero od początku $\mathrm{V}$ wieku na Wschodzie.

Jednym z najstarszych dokumentów poświadczających istnienie instytucjonalnych domów starców, jest inskrypcja na listwie kamiennej $(1.50 \times 0,42 \mathrm{~m})$, umieszczona w murze przy obecnej Bramie Heroda (Bab-ez-Zahireh) w Jerozolimie, pochodząca z jakiegoś wcześniejszego starożytnego hospicjum, która informuje nas o istnieniu w tym mieście ,domu starców dla ubogich kobiet, założonym w imię Matki Bożej przez Jana i Werynę z Bizancjum ${ }^{174}$. Potem Palladiusz w swojej Historia Lausiaca opowiada o jednym z braci, który otrzymawszy część majątku po śmierci ojca, ,zbudował klasztor, a przybrawszy sobie kilku braci, przyjmował wędrowców, chorych, starców i biedaków, w soboty zaś i w niedziele zastawiał dla nich trzy albo cztery stoły"175.

Podobnie na Zachodzie Paulin z Noli († 431) zbudował przy sanktuarium św. Feliksa w Noli piętrowe hospicjum, przeznaczone głównie dla starszych pielgrzymów, z wydzielonymi w nim ławami dla staruszków, staruszek i żebraków ${ }^{176}$. Ponad wiek później papież Pelagiusz II (578-590) „uczynił swój dom przytułkiem dla biednych starców"177, a potem również jego następca papież Grzegorz Wielki (590-604) informuje nas o ,przytułku dla starców, zbudowanym przez niejakiego Izaura, w którym jednak brak łóżek i pościeli”, dla którego przesyła 15 koców, 30 sukien i 15 łóżek oraz pieniądze na kupno poduszek lub materaców ${ }^{178}$. W tym samym czasie na Wschodzie Kodeks Justyniana poświadcza istnienie, obok sierocińców i domów dla ubogich, także instytucjonalnych

${ }^{173}$ Por. Mattioli, Assistenza e cura dei malati nell'antichità cristiana, s. 245-278 (też bibliografia n. 2); A. Harnack, Medicinisches aus der ältesten Kirchengeschichte, TU 8/4, Leipzig 1892; H. Frings, Medizin und Arzt in den griechischen Kirchenvätern bis Chrysostomos, Bonn 1959; T.S. Miller, The birth of the hospital in the Byzantine Empire, Baltimore - London 1985, 1997². O stosunku do chorego pacjenta zob. A. Schadewaldt, Arzt und Patient in antiker und früchristlicher Sicht, „Medizinische Klinik" 59 (1964) 146-152; G. Harig - J. Kollesch, Arzt, Kranker und Krankenpflege in der griechisch-römischen Antike und bizantinischen Mittelalter, „Helikon” 13-14 (1973-1974) 252-292. Bibliografia do r. 1997 zob. „Lettre d'informations” 1996, nr 26-28; 1997, nr 29.

174 Por. Germer-Durand, Épigraphic chrétienne de Jerusalem, „Revue Biblique” 1 (1892)

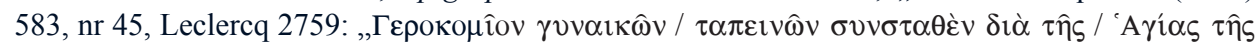

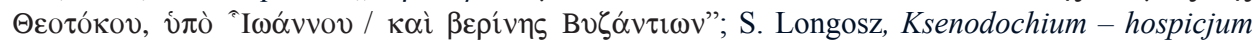
wczesnochrzescijańskie, VoxP 16 (1996) t. 30-31, ss. 301, 306, 311, 313, 317.

${ }^{175}$ Palladius, Historia Lausiaca 14, 3, ed. G.J.M. Bartelink, s. 60, thum. S. Kalinkowski, ŹM 12 , Kraków - Tyniec 1996, 104.

${ }^{176}$ Por. Paulinus Nolanus, Carmina XX 114-116, CSEL 30, 147: „Dispositi trino per longa sedilia coetu / Obstrepuere senes, inopum miserabile vulgus / Et socio canae residentes agmine matres".

${ }^{177}$ Por. Liber Pontificalis, ed. L. Duchesne, vol. I, Paris 1955, 309: „Hic domum suam fecit ptochium pauperum senum".

${ }^{178}$ Por. Gregorius Magnus, Epistolae XI 2, CCL 140A, 860: „Filio nostro Simplicio renuntiante cognovimus lectos vel lectisternia in hierochomio, quod a quodam illic Isauro constructum est, deesse”, thum. J. Czuj: Św. Grzegorz, Listy, IV, Warszawa 1955, 37. 
domów starców (gerontocomia) z rozciągniętą nad nimi opieką państwową ${ }^{179}$, a także istnienie ich specjalnego przełożonego - gerontokoma ${ }^{180}$. Potem świadectwa o ich istnieniu sa już coraz liczniejsze: jeszcze w VI wieku wspomina o nich biskup Homerytów Gregencjusz, zabraniający ich mieszkańcom żebrania w miejscach publicznych ${ }^{181}$, Cyryl ze Scytopolis ${ }^{182}$, biskup Leoncjusz z Neapolis na Cyprze ${ }^{183}$, czy Maksym Wyznawca († 662) informujący, w jednym ze swych listów, że prefekt Jerzy (Georgius) zbudował wiele szpitali i domów dla starców - gerontokomiów ${ }^{184}$. Tak więc geriatria, zajmująca się zorganizowaną opieką nad ludźmi starymi oraz leczeniem ich dolegliwości, jest zjawiskiem późniejszym, a u jej podstaw znalazło się chrześcijaństwo ze swoim przykazaniem miłości bliźniego, które najpierw stworzyło ksenodochia i szpitale, potem sierocińce i przytułki dla ubogich, a później także instytucjonalne domy starców - gerontokomia. Zalaż̇i tych ostatnich, podobnie jak i geriatrii jako dyscypliny medycznej, spotykamy już w starożytności chrześcijańskiej, dalszy jej rozwój w średniowieczu, a rozkwit w XX wieku.

\section{MEDICAL CARE OF OLD PEOPLE IN THE GRECO-ROMAN WORLD}

\section{(Summary)}

The article talks about the medical care for older people in ancient Greco-Roman world. The Presocratic theory about warm and moisture was generally admitted in Antiquity. They confected that the human body receives the most portion of warm and moisture with birthday human being and lost this in the course of life. After all, as the elderly is cold and dry. The Treatment of disease rested on prevention of Dehydration and Hypothermia by appropriate diet. The article is consisting of three chapters: The first chapter reminds essential theory about warm and moisture, and presented the types of medicine especially from Hippocrates school. The Hippocratic myth has been popularized by Aristotle. The followers of Hippocrates have detected diseases and afflictions of old age. Their therapy was restricted to apply alimentary diet. The second chapter appears

179 Por. Codex Justinianus I 2, 22: „Sancimus res ad venerabiles ecclesias vel xenones vel monasteria vel ptochotrophia vel brephotrophia vel orphanotrophia vel gerontocomia vel si quid aliud tale consortium descendentes ex qualicumque curiali liberalitate sive inter vivos sive mortis causa sive in ultimis voluntatibus habita lucrativorum inscriptionibus liberas immunesque esse".

${ }^{180}$ Por. Novellae Justinianae VII 12: „oeconomus autem, qui tale aliquid egerit aut abbas aut xenodochus aut nosocomus aut ptochotrophus aut orphanotrophus aut gerontocomus de suo ei, qui dedit, salvabit ex hoc damnum".

${ }^{181}$ Por. Gregentius Tapharensis, Leges Homeritarum 55, PG 86, 580B, 609B: „Wszystkim ubogim z sierocińców i domów starców ( $\gamma \eta \rho о \kappa о \mu \varepsilon \hat{\imath} \alpha)$ zakazujemy, by nikt z nich na rynku, w kościołach lub innym jakimś publicznym miejscu nie prosił o chleb".

${ }^{182}$ Por. Cyrillus Scythopolitanus, Vita Euthymii 35, ed. E. Schwartz, TU 49/2, Berlin 1939, 53, 6.

${ }^{183}$ Por. Leontius Neapolitanus, Vita Joannis Eleemosynarii 45, ed. H. Gelzer, s. 93, 20.

${ }^{184}$ Por. Maximus Confessor, Epistolae 44, PG 91, 648A: „Dziełem zaś prefekta Jerzego są wzniesione szpitale i domy starców" ( $\gamma \eta \rho о \kappa о \mu \varepsilon \hat{\imath} \alpha)$. 
analogous therapy, which had been presented in the patristic period, moved by Galen and his followers. Their therapy included not only alimentary diet, but also massages, gymnastics, walks, baths, moistening and rubbing a diseased part with soil, pharmaceutical, aesthetic or surgical therapy. The third chapter deals with two proposals of old people therapy - Galen's (diet, exercises, program of old man life and emulation the way of life long-lived people) and Celsius's (adjustment of diet to the age and season) then surgical, pharmaceutical and aesthetic therapies, which were applying for the meantime. The article concludes that Ancient Christians, in addiction to this issue, created the germs of old people's homes (Gerontocomia). 